Canadian Science Publishing

Canadian Journal of Earth Sciences Revue canadienne des sciences de la Terre

\title{
Petroleum generation modeling of the organic-rich shales of Late Jurassic-Early Cretaceous succession from Mintaq-01 well in the Wadi Hajar sub-basin, Yemen
}

\begin{tabular}{|r|l|}
\hline Journal: & Canadian Journal of Earth Sciences \\
\hline Manuscript ID & cjes-2015-0224.R2 \\
\hline Manuscript Type: & Article \\
\hline Date Submitted by the Author: & 18 -May-2016 \\
\hline Complete List of Authors: & $\begin{array}{l}\text { Hakimi, Mohammed; Taiz University, Geology } \\
\text { Ahmed, Abdulghani ; Taiz University, Geology }\end{array}$ \\
\hline Keyword: & $\begin{array}{l}\text { Organic-rich shale, petroleum generation modeling, Wadi Hajar sub-basin, } \\
\text { Yemen, Late Jurassic-Early Cretaceous }\end{array}$ \\
\hline
\end{tabular}

SCHOLARONE ${ }^{\text {MN }}$

Manuscripts 


\title{
Petroleum generation modeling of the organic-rich shales of Late Jurassic-Early Cretaceous succession from Mintaq-01 well in the Wadi Hajar sub-basin, Yemen
}

\author{
Mohammed Hail Hakimi", Abdulghani F. Ahmed \\ Geology Department, Faculty of Applied Science, Taiz University, 6803 Taiz, Yemen
} ibnalhakimi@yahoo.com

\begin{abstract}
Late Jurassic-Early Cretaceous shales of the Naifa, Safer and Madbi formations were studied to evaluate source rock characterisation. The results of the source rock were then incorporated into basin modeling to understand the timing of hydrocarbon generation and expulsion. The Late Jurassic-Early Cretaceous shales have low to high organic matter, with TOC values in the range of $0.50 \%-28.01 \%$, indicating fair to excellent source rock potential. Main oil and gas are anticipated to be generated from the Naifa, Safer and Lam shale samples with Type I/II and Type II-III kerogens. In contrast, the Meem samples are dominated by Type III kerogen ( $\mathrm{HI}<200 \mathrm{mg} \mathrm{HC} / \mathrm{g}$ TOC), and are thus considered to be gas-prone. The Late Jurassic-Early Cretaceous shale samples have pyrolysis $\mathrm{T}_{\max }$ in the range of $337-515^{\circ} \mathrm{C}$, consistent with immature to post-mature stages. The $\mathrm{T}_{\max }$ data also indicate that the Safer and Madbi shale samples have sufficient thermal maturity i.e., peak-mature of oil and gas window.

The basin models indicate that the Naifa Formation is early mature and the onset oilgeneration began during the Early Miocene. The models also indicate that the main phase of oil-generation in the Safer source rock began during the Late Eocene. In contrast, the Madbi source rock units are passed the peak oil-generation window and the oil was converted to gas during the Late Cretaceous to Late Eocene. The modeled hydrocarbon expulsion history reveals that most of oils are contributed by both Madbi units, with significant amounts of gas originating from the Meem unit.
\end{abstract}


Keywords: Late Jurassic-Early Cretaceous; Organic-rich shale; Rock-Eval pyrolysis; petroleum generation modeling; Wadi Hajar sub-basin; Yemen

\section{Introduction}

The area of interest of this study is the Wadi Hajar sub-basin, forming the east-south part of the Sabatayn Basin (Fig. 1). The Sabatayn Basin is known by a variety of names, such as Sabatayn Basin, Marib-Shabowah-Hajar Basin (Beydoun et al. 1998) and MaribShabowah Basin (Brannin et al. 1999; Csato et al. 2001). The Sabatayn Basin is a Mesozoic sedimentary basin across the western Yemen (Fig. 1) that was formed as a result of rifting basin linked to the Mesozoic breakup of Gondwanaland (Redfern and Jones 1995).

The Sabatayn Basin contains proven commercial quantities of HCs (i.e., oil and gas), and has attracted the interest of numerous researchers, authors and oil companies (e.g., Brannin et al. 1999; Csato et al. 2001; Alaug et al. 2011; Hakimi and Abdullah 2013a, b; Hakimi et al. 2014; Hakimi and Abdullah 2015). All these publications have been done in north part of the Sabatayn Basin (i.e., Marib sub-basin). However, the Wadi Hajar subbasin is one of the hydrocarbon exploration frontier regions in western Yemen where very few data are available for the adequate assessment of the hydrocarbon generation potential. The first drilled well in Wadi Hajar sub-basin is Mintaq-01 well, which was drilled by the Total Oil Company in early 1989. The Mintaq-01 well was reached the Precambrian basement rocks with total depth $3750 \mathrm{~m}$ (unpublished report). The oil and condensate shows are also discovered within the Madbi sandstone reservoir rock in the Mintaq-01 well (unpublished report). Howerver, the Mintaq-01 well was chosen because the well are drilled to depths that penetrated a significant part of the Late Jurassic-Early 
Cretaceous source rock units of interest, and have organic geochemical results. In this respect, the present study focuses on the evaluation of organic matter type, richness, thermal maturity and hydrocarbon generation potential of the thick Late Jurassic-Early Cretaceous organic-rich sedimentary rocks in this sub-basin. In addition, the results of source rock characterisation are incorporated into basin models in order to know and determine the timing of hydrocarbon generation and expulsion of the Late Jurassic-Early Cretaceous source rocks. This study is expected to provide further insight into the source rocks in the Wadi Hajar sub-basin, and responsible for further exploration success and resource assessment in the whole Sabatayn Basin.

\section{Geologic setting}

The Sabatayn Basin, onshore sedimentary basins, is situated in western Yemen (Fig. 1), which is developed as a rift-basin during the Late Jurassic-Early Cretaceous during the Mesozoic breakup of Gondwanaland and the evolution of the Indian Ocean (Redfern and Jones 1995). The main stratigraphy section of the Sabatayn Basin contains more than $4 \mathrm{~km}$ of Jurassic to Tertiary in thickness (As-Saruri et al. 2010). Based on subsurface exploration wells and previous studies (e.g., As-Saruri et al. 2010), the Wadi Hajar subbasin contains sedimentary rocks range from Jurassic to Tertiary time (Fig. 2). On top of the Precambrian basement rests the Kuhlan and Shuqra formations, which were deposited during Middle to Early Jurassic time (Fig. 2). The Kuhlan Formation includes fluviatile and arkosic red beds that grade upward into the shallow-marine facies of Shuqra Formation, the latter represents the early transgressive sediments of the Late Jurassic (Beydoun et al. 1998). The sediments of the overlying Madbi Formation were deposited during the Kimmeridgian time (Beydoun et al. 1998). In the Sabatayn sub-basins, the 
Madbi Formation has been divided into two members: Meem and Lam members (Oldest to youngest) (Fig.2). The Meem member consists of turbidite sandstones, shales and claystones (Fig.2). The upper Lam member is mostly organic-rich shale sediments (Fig.2). The sediments of Madbi Formation reflect a marine environment setting (Beydoun et al. 1998; Hakimi et al. 2012a, 2014). The Tithonian Sabatayn Formation is overlying the Madbi Formation, which was deposited during ocean circulation in the western part of Yemen (Beydoun et al. 1998). The Sabatayn Formation consists of thick sequence of clastic and evaporite sediments with interbedded shales (Fig. 2). The Alif Member is considered as the main reservoir for Jurassic petroleum system in the MaribShabowah sub-basin (JNOC, 2000 "personal communication"). The Safer Member constitutes an excellent seal to the underling Alif Member reservoir and contains interbedded organic-rich shales. The interbedded organic-rich shales are considered to be oil-source rock in the Marib sub-basin (Hakimi and Abdullah 2013a). The rifting system of the Sabatayn Basin continued during latest Jurassic to Early Cretaceous, but the subsidence showed down. This causes the deposition of shallow water carbonates, the Naifa Formation, lying conformably on top of the Sabatayn Formation (Fig. 2). During Early to Late Cretaceous, post-rift sediments accumulated in the basin forming the Saar, Qishn, Harshiyat/Fartaq, Mukalla, and Sharwyn formations. The earliest Cretaceous Saar Formation is composed mainly of limestone and dolomitic limestone with some mudstone and sandstone intercalations (Fig. 2). The Qishn Formation overlies the Saar Formation unconformably and can be divided into two members: (1) Qishn clastic member and (2) Qishn carbonate member (Beydoun et al. 1998). The Qishn clastic member is considered to be the main reservoir rock in the Masila Basin (King et al. 2003; 
Hakimi et al. 2012b). The Late Cretaceous Harshiyat Formation is composed of mainly sandstones and interbedded shales, which were deposited in fluvial-deltaic to shallow marine setting (Beydoun et al. 1998), with vertical variations of thickness and lateral facies to the Fartaq Formation (Fig. 2). The Late Cretaceous Mukalla Formation is underlain conformably by Harshiyat/ Fartaq sediments, which is composed of sandstones and intercalated with shales and coal beds (Fig. 2). The Sharwyn Formation is composed of shallow marine limestones and marls (Fig. 2). In the Late Paleocene, sea level rose and resulted in the formation of transgressive shale deposits at the base of the Umm Er Radhuma carbonate Formation. The Umm Er Radhuma Formation continued to the Early Eocene and followed by anhydrite of the Jiza, Rus and Habshiyah formations (Fig. 2).

\section{Samples and methods}

A total of 260 cuttings samples of organic-rich shale intervals within the Late JurassicEarly Cretaceous formations (40 samples from Naifa Formation, 16 samples from Safer Formation and 204 samples from Madbi Formation) were collected from Mintaq-01 well in the Wadi Hajar sub-basin of the Sabatayn Basin (Table 1). The drilling mud contaminated samples were water washed prior to geochemical analysis.

\subsection{Organic geochemical analysis}

Basic organic geochemical analysis (i.e., total organic carbon (TOC) content and RockEval pyrolysis) is presented in this study. Organic geochemical analysis was conducted at Simon Petroleum Technology Limited Laboratories, United Kingdom, and the results

provided by Petroleum Exploration and Production Authority (PEPA), Republic of Yemen (Personal communication). 
The whole rock samples were crushed to powder and analysed by a LECO CS125 instrument that can provide measurements of the total organic carbon (TOC) content. The samples were subsequently screened by Rock Eval-II instrument, which were heated to $600^{\circ} \mathrm{C}$ in a helium atmosphere and several parameters such as free hydrocarbons $\left(S_{1}\right)$ in the rock, remaining hydrocarbon generative potential, $\mathrm{mg} \mathrm{HC} / \mathrm{g}$ rock $\left(S_{2}\right)$, and temperature of maximum pyrolysis yield $\left(\mathrm{T}_{\max }\right)$ were measured. Hydrogen index $(\mathrm{HI})$, production index $(\mathrm{PI})$ and petroleum potential yield (PY) were subsequently calculated (Table 1).

Vitrinite reflectance measurements were also performed on polished block for some shale samples. Mean vitrinite reflectance (Ro\%) was conducted on particles of vitrinite maceral that are not associated with strong bitumen staining using a microscope with white light source and oil immersion objectives. Typically, 20 measurements were made for each sample, but the low organic matter content limited the number of points counted in some samples.

\subsection{Basin modeling procedure}

In this study, Mintaq-01 well was chosen as a representative site to reconstruct the burial and thermal histories and to simulate the petroleum generation and expulsion of the Late Jurassic-Early Cretaceous source rocks in the Wadi Hajar sub-basin.

PetroMod 1-D (version 10.0 SP1) software developed by Schlumberger was used to reconstruct the burial and thermal history of the studied well. Subsequently, the maturity of the source rocks and the timing of $\mathrm{HC}$ generation and expulsion could be modelled. Good knowledge of the lithologies of the sedimentary section, their ages and periods of deposition and erosion are necessary for the evaluation of basin evolution (Lerche 1990). 
The geologic model consisting of the depositional, non-depositional in absolute ages (Table 2), was compiled using stratigraphic data from well report and previous stratigraphy studies (e.g., Beydoun et al. 1998). In addition, the erosional events is also estimated and used to reconstruct the burial history. Based on the pervious works (e.g., Beydoun et al. 1998; As-Saruri et al. 2010) of the ideal stratigraphic section of the sedimentary basins of Yemen, there are three missing formations in the Mintaq-01 well (i.e., Saar, Sharwayn and Jiza formations). These formations were deposited during 140.2-136.4 Ma, 71.0-65.5 Ma and 58.7-43.2 Ma, respectively (Table 2). These three missing formations were considered as erosion events in the model (Table 2). Howerver, the erosional thicknesses were estimated by the average depositional thicknesses of these missing formations from subsurface well data described by previous published works studies (Hakimi et al. 2010; Hakimi and Abdullah 2015). A total amount $500 \mathrm{~m}$ erosional thickness was considered in the model (Table 2).

The heat flow history is also needed as a basic input parameter, which was reconstructed based on the general tectonic evolution of the area of interest and finally fine-tuned to match the calibration data such as vitrinite reflectance and temperature data. Maturity of vitrinite was simulated using the EASY\%Ro model by Sweeney and Burnham (1990).

\section{Results and discussion}

\subsection{Source rock characteristics}

Source rock characteristics were conducted by TOC content and Rock Eval-pyrolysis results (Fig. 3) to investigate the quantity and quality of organic matter, thermal maturity, and hydrocarbon generation potential of the Late Jurassic-Early Cretaceous organic-rich 
shales in the Mintaq-01, Wadi Hajar sub-basin. The source rock properties i.e., total organic carbon (TOC) content and type of organic matter (kerogen) were used in basin modeling to simulate the hydrocarbon generation and expulsion history.

\subsubsection{Source rock generative potential}

The source rock generative potential of the Late Jurassic-Early Cretaceous shales was evaluated using total organic carbon (TOC) content and pyrolysis $S_{1}$ and $S_{2}$ yields (Table 1). The $S_{1}$ and $S_{2}$ yields together make up the petroleum potential yield; thus, the sum of these two parameters is referred to as PYs. However, the TOC values is usually used to estimate the organic richness of a sedimentary rock (Peters and Cassa 1994; Hunt 1995). The Late Jurassic-Early Cretaceous shale samples have low to high TOC content values (0.50-28.01 Wt. \%), revealing fair to excellent source rocks (Fig. 4). The organic source rock generative potential was also evaluated from the amount of hydrocarbon yield $\left(S_{2}\right)$ generated during pyrolysis process (Peters 1986; Bordenave 1993). The $S_{2}$ yields for the Late Jurassic-Early Cretaceous shale samples range from 0.15 to $158.86 \mathrm{mg} \mathrm{HC} / \mathrm{g}$ rock (Table 1), thus are in agreement with TOC contents and considered to be a fair to excellent source generative potential (Fig. 5a). The Safer, Naifa and Lam source rock samples are higher generative potential than Meem source rock samples (Fig. 5a). In addition, the relationship between genetic petroleum potential yield $(S 1+S 2)$ and total organic carbon (TOC) content also confirms that the majority samples of the Late Jurassic-Early Cretaceous have good genetic petroleum potential, with PY values more than $2.5 \mathrm{mg} \mathrm{HC} / \mathrm{g}$ rock (Fig. 5b). The source rock characteristics of the Upper Jurassic Safer and Lam in this study are consistent with those of the Sabatayn and Lam source 
rocks in the Tagina South-1 (Sachsenhofer et al. 2012), which is very close in location to the studied well.

\subsubsection{Type of organic matter and petroleum generation potential}

The organic matter type (kerogen) was characterized based on Rock Eval pyrolysis data, such as Hydrogen Index (HI). The Late Jurassic-Early Cretaceous source rock samples have $\mathrm{HI}$ values range between 8 and $738 \mathrm{mg} \mathrm{HC} / \mathrm{g}$ TOC (Table 1). Based on kerogen classification HI versus $\mathrm{T}_{\max }$ plot (Fig. 6), the Meem shale samples contain kerogen Type-III (Fig. 6), with HI values less than $200 \mathrm{mg} \mathrm{HC/g}$ TOC. In contrast, the Safer, Naifa and Lam shale samples contain Type I and II kerogens through Type II and III kerogens (Fig. 6), with HI values range from 76 to $738 \mathrm{mg} \mathrm{HC/g}$ TOC. Therefore, the Safer, Naifa and Lam shale samples would be expected to generate mainly oil and gas, consistent with kerogen Types I/II and II-III. The Meem shale samples with a dominant contribution of Type III kerogen would generate mainly gas, if mature.

\subsubsection{Maturity of organic matter}

The level of thermal maturity of organic matter in the Late Jurassic-Early Cretaceous source rock samples were evaluated based on Rock Eval pyrolysis $\mathrm{T}_{\max }$ and production index (PI) data (Table 1). The Late Jurassic-Early Cretaceous source rock samples have Rock Eval pyrolysis $\mathrm{T}_{\max }$ values between 337 and (Table 1). The Safer and Madbi units (Lam and Meem) samples have $\mathrm{T}_{\max }$ values more than $430^{\circ} \mathrm{C}$, and thus they are higher thermally mature than Naifa samples, and consistent with early mature to post mature stages (Fig. 6). However, the samples of Safer and Madbi source rock with lower $\mathrm{T}_{\max }$ values $\left(<430^{\circ} \mathrm{C}\right)$ may probably be due to the presence of migrated hydrocarbons (e.g., Peters 1986; Shalaby et al. 2012) or contamination of oil base mud (e.g., Peters 1986; 
Issler et al. 2012). The migrated hydrocarbons are confirmed by high production index (PI) values (Fig. 7). Furthermore, the relationship between production index (PI)and $\mathrm{T}_{\max }$ thermal maturity indicators reflects the same maturity levels of the organic matter. The Naifa samples are immature to early mature source rocks, while the Safer and Madbi units are thermally mature and generally within the petroleum generation stage (Fig. 7).

\subsection{Basin modeling concept}

\subsubsection{Burial history modeling}

The main parts of the $1 \mathrm{D}$ modeling results are burial and tectonic subsidence histories. The burial (subsidence) and thermal histories are necessary in order to predict timing of hydrocarbon generation and expulsion. The burial history was reconstructed based on stratigraphic descriptions taken from well report. Together with lithological information, which reveal the compaction behavior, back stirring can be performed to receive a burial history including decompacting (Table 2). The subsidence curves and basin history filling of the studied well are represented in Figure 8. The burial history illustrates that the prerift section associated with thin sediments while the syn-rift and post rift exhibit a thick sediments (Fig. 8).

The burial history demonstrates that there was an initial phase of slow subsidence in the pre-rift sedimentary rocks $(163-155.7 \mathrm{Ma})$. The pre-rift phase includes Kuhlan and Shuqra formations and was characterized by low subsidence rates of about $\sim 9 \mathrm{~m}$ per million years leading to a present thickness of about $64 \mathrm{~m}$ (Table 2). This period was followed by syn-rift phase with rapid subsidence during Late Jurassic to Early Cretaceous constituting the main rift phase (Table 2). The subsidence and sedimentation during the Late Jurassic to Early Cretaceous $(\sim 155.7-\sim 145 \mathrm{Ma})$ are much higher $(\sim 201 \mathrm{~m}$ per 
million years), leading to a total thickness of $\sim 2148 \mathrm{~m}$. The overlying post-rift phase during Early Cretaceous to Tertiary ( 145-24.9 Ma) were also characterized by relatively high sedimentation rates, resulted in deposition of thick sedimentary successions with a total thickness of 1489 m. However, the overburden rocks of Early Cretaceous to Tertiary have an influence on syn-rift Madbi and Safer source rocks maturation and the petroleum generation can be expected around this time.

\subsubsection{Heat flow and thermal history}

The heat flow is crucial in the basin modeling and used to help reconstruction thermal maturity modeling. The heat flow of sedimentary basins can be evaluated based on the tectonic evolution and rifting phase (Lachenbruch 1970; Allen and Allen 1990). The rifting history influences heat flow. A higher heat flow is incorporated into episodes during the rifting phase and an exponential reduction in heat flow is considered during the post-rift phase (Mckenzie 1978). The palaeo-heat flow models are usually calibrated with thermal maturity data such as vitrinite reflectance measurements (e.g., Welte and Yukler 1981, 1987; Poelchau et al. 1997; He and Middleton 2002; Li et al. 2010; Hakimi et al. 2010; Shalaby et al. 2011, 2013). Moreover, the present-day heat flow can also be estimated from thermal conductivities of the rock units and subsurface geothermal gradients, which are determined from corrected bottom hole temperatures (BHT) (e.g., Abdalla et al. 1999).

In this study, the heat flow is estimated using the regional heat flow in the north part of the Sabatayn Basin (Marib sub-basin) as indicated by earlier works of Hakimi and Abdullah (2015). Hakimi and Abdullah (2015) were estimated the heat flow is in the range of $60-95+\mathrm{mW} / \mathrm{m} 2$. The present day heat flow was inferred from fair to good 
matching between corrected bottom hole temperature and modeled (calculated) temperature curves (Fig. 9). The present-day geothermal suggests heat flow may currently be $(60 \mathrm{~mW} / \mathrm{m} 2)$ at Mintaq-01 well (Fig. 10c). The paleo-heat flow was the result of the fit between measured and modeled vitrinite reflectance profile. A very good correlation between measured and calculated \% Ro values implies that the thermal model is valid for this study area (Fig. 10b) and indicate that the heat flow increased from background values $(60 \mathrm{~mW} / \mathrm{m})$ during the initial phase $(155.7 \mathrm{Ma})$ of syn-rifting stage in the basin and reached peak heat-flow values of approximately $97.0 \mathrm{~mW} / \mathrm{m} 2$ at $150 \mathrm{Ma}$ (Fig. 10c). This peak is related to the initial rifting event starting the basin development (Late Jurassic time; Redfern and Jones 1995). These heat flow values $\left(60-97 \mathrm{~mW} / \mathrm{m}^{2}\right)$ were applied and considered for the maturity modeling of the source rocks in this study (Fig. 10a).

\subsubsection{Maturity history modeling of the source rocks}

The maturation history was used to determine the time when the source rocks passed through the oil window maturity. The modeled maturity history of the Late Jurassic-Early Cretaceous source rocks reflects that the hydrocarbon generation history of the source rocks are difference because of variation in their thermal and buried histories (Fig. 10a).

The Naifa source rock is still in the early-mature stage of oil generation $(0.55$ $\%$ Ro),which was reached during the Miocene time at 21Ma (million years ago )(Fig. 10a). The Safer source rock has entered the early-mature of oil window during the Late Eocene $(41 \mathrm{Ma})$ and the peak oil-generation was reached during the Late Oligocene at 27 Ma (Fig. 10a). In contrast, the oil generation stages of the Madbi source rock units (Meem and Lam) began during earlier time due to the high levels of thermal maturity 
(Fig. 10a). These higher levels of maturity of the Madbi source rock were probably attribute to the buried histories (Fig. 10a).

In the Lam unit, the source rock was reached the early-mature stage of oil generation during the Cretaceous (140-90 Ma) (Fig. 10a). The peak oil-generation of the Lam source rock unit was started during the Eocene (53 Ma), with computed vitrinite reflectance values of $0.70 \%$ Ro (Fig. 10a). Furthermore, the late oil generation was also occurred during the Eocene at $30 \mathrm{Ma}$ and continued to the present-day, with vitrinite reflectance values between 1.0 and 1.13 Ro\% (Fig. 10a). Compared with Lam unit, the peak and late oil generation window of the Meem source rock have reached earlier time during the Late Cretaceous ( 98Ma) and the Early Eocene (50 Ma), respectively (Fig. 10a). These higher levels of maturity of the Meem source rock were probably due to the thermal and buried histories. Moreover, the gas window of the Meem source rock was also reached during the Late Eocene (37 Ma), and continued to present-day (Fig. 10a).

4.2.4. Timing of hydrocarbon generation and expulsion from source rocks

The timing of hydrocarbon generation and expulsion from Late Jurassic-Early Cretaceous source rocks were analysed based on maturation history using an assumed 10\% transformation ratio (Figs. 11 and 12). The hydrocarbon generation and expulsion stages were also calculated using difference reaction kinetics data based on source rock parameters (i.e., HI and TOC). The modeled hydrocarbon generation and expulsion history of the Late Jurassic-Early Cretaceous source rocks in the studied well shows difference of HC (i.e., oil and gas) products because of variation in transformation ratios (TR) and reaction kinetic data (Figs. 11 and 12). 
The Naifa Formation is still a very early-mature source rocks, therefore, the oil has not yet generated (Fig. 11a). This is due to its lower thermal maturity with transformation ratio (TR) less than 10\% (Fig. 11b).

The kerogen type in the Safer source rock is Type II-S kerogen as indicated from: (1) very low $\mathrm{Pr} / \mathrm{Ph}$ ratios (Hakimi and Abdullah 2013a), (2) high sulfur contents; (3) low maturity level of generated oil (Hakimi and Abdullah 2013b), (4) association Safer shale source rock with evaporite deposits (Fig. 2). Therefore, the hydrocarbon generation history of the Safer source require a special kinetic model (i.e., Type II-S kerogen reaction kinetic data). Based on the maturity and reaction kinetic data of the Safer source rock, the hydrocarbon generation and expulsion history model can be divided into two stages (Fig. 11). The first stage of hydrocarbon generation was occurred during the Late Eocene (approximately 38-35 Ma). This stage is the early phase of oil-generation, with TR between $10 \%$ and $25 \%$ (Fig. 11b). The second stage (approximately $35-5 \mathrm{Ma}$ ) is the main phase of oil-generation. In this stage, the TR ranges from $25 \%$ to $50 \%$ (Fig. $11 \mathrm{~b}$ ), with computed VR in the range of $0.63-0.73 \%$ Ro. Therefore, the Safer oil is an early generated product from a high S- kerogen. The limited oil also expelled during this stage because of significant amounts of oil-generation, with TR more than 50\%. (Fig. 11b ). This is supported by the presence of expelled and migrated hydrocarbon within the Safer source rock samples as indicated by high PI values (Fig. 7).

In the Madbi source rock units (i.e., Meem and Lam), hydrocarbon generated and expelled in the earlier time due to their deeper burial depth (2329-3647m). Howerver, the hydrocarbon generation history of the Madbi source rock units was modelled based on a 
Type II kerogen gradient to type II-III kerogen kinetic model (i.e., IES Kimmeridge Clay kinetic model).

The hydrocarbon generation and expulsion history from Meem source rock unit began earlier compared to Lam source rock unit because the higher maturity levels of the Meem unit compared to Lam unit. The hydrocarbon generation and expulsion history were modeled as four main stages (Fig. 12). The first stage (approximately 98-61 Ma) is the early phase of oil generation without any expulsion (Fig. 12a). The TR of this stage ranges between $10 \%$ and $25 \%$ (Fig. 12b). The second stage was occurred at 61-42 Ma, which represents the main phase of oil generation and significant amount of gas was generated (Fig. 12a), with calculated TR and VR values in the range of $25 \%$ to $50 \%$ and 0.85-1.09\% Ro, respectively (Fig. 12b). The oil was also expelled during this stage, with TR more than $50 \%$. The main stage of oil expulsion was reached between 42 and $30 \mathrm{Ma}$, with increased TR from $50 \%$ to $81 \%$ (Fig.12b). The last stage was started during the Oligocene time (30 Ma) and continued to present day (Fig. 12a). The significant gas was expelled from the Meem source rock unit during this stage, with TR ratio of the range 81 $\%-95 \%$ (Fig. 12b). In contrast, the oil generation and expulsion model of the Lam source rock unit were modeled in three main phases (Fig. 12). The Lam source rock starts generating oil during the Eocene (approximately 55-37 Ma) (Fig. 12a), with TR of the range $10 \%-25 \%$ (Fig. 12b). The main phase of oil generation was reached at approximately 37-26 Ma, with TR values between 25\% and 50\% (Fig. 12b). The gas generation can also be expected in this stage from reaching the maximum transformation ratio (TR $>40 \%$ ) and calculated VR of the range $0.86-1.10 \%$ Ro. In the last phase, the significant oil was expelled from Lam source rock during the Late Oligocene (26 Ma) to 
present-day with TR value more than 50\% (Fig. 12b). Looking at the amount and phase of expelled hydrocarbons from the Madbi source rock units reveal quickly that significant oil and gas were expelled so that a successful charge of any nearby prospect is likely. This is in agreement with the presence of oil and condensate shows exist along the Madbi reservoir rocks as confirmed by the drilling activity in the Mintaq-01 well (unpublished repot). The hydrocarbon generation modeling in this study is also compared to the previous study (i.e., Sachsenhofer et al. 2012). Sachsenhofer et al. (2012) have modeled the hydrocarbon generation history of the Upper Jurassic source rocks in the Tagina South-1 well, Sabatayn Basin. The Tagina South-1 well is very close in location to the studied Mintaq-01 well. They suggested that the major hydrocarbon generation of the Upper Jurassic source rocks (i.e., Safer and Lam) occurred during both, Late Cretaceous and Eocene-Oligocene times. These results are similar with the modeling results in this study, which are indicated that the Upper Jurassic source rocks (i.e., Safer and Lam) began generated hydrocarbons during Late Cretaceous to Late Eocene.

\section{Conclusions}

Late Jurassic-Early Cretacouse organic-rich shales of the Naifa, Safer and Madbi formations from Mintaq-01 well in the Wadi Hajar sub-basin were analysed for organic geochemistry of whole rock (i.e., total organic carbon content and Rock-Eval pyrolysis) and the results were then incorporated into basin modeling. The results obtained in this study give a strong indication as follows:

1- The Late Jurassic-Early Cretacouse organic-rich shales are potentially important petroleum source rocks. . They have low to high organic matter with TOC values in the range of $0.50-28.01 \mathrm{wt} . \%$, indicating fair to excellent source rock potential. 
However, the Late Jurassic Safer and Madbi source rocks are relatively higher in genetic petroleum potential.

2- The shale samples of the Naifa, Safer and Lam contain Type I/II and II-III kerogens with HI values in the range of $76-738 \mathrm{mg} \mathrm{HC} / \mathrm{g} \mathrm{TOC}$, which can be expected to generate mainly oil and gas HCs. In contrast, the Meem source rock contains Type III kerogen with HI values less than $200 \mathrm{mg} \mathrm{HC} / \mathrm{g}$ TOC and considered to generate gas.

3- Maturity data such as Rock Eval pyrolysis $T_{\max }$ and PI show that the Naifa source rock samples are thermally immature to early-mature, while the Safer and Madbi (i.e., Lam and Meem units) samples are early-mature to post-mature source rocks.

4- The basin models indicate that the Safer and Madbi formations are an effective oil-source rocks in the Wadi Hajar sub-basin. The oil was early generated from Safer source rock during the Late Eocene time (35 Ma). In contrast, the peak of oil-generation of the Madbi units (Meem and Lam) was passed in the earlier time (Early Eocene and Early Oligocene, respectively), and the oil was converted to gas from Meem unit during the Late Eocene time.

5- The modeled hydrocarbon expulsion suggests that the timing of hydrocarbon expulsion from the Madbi units began in the Late Eocene and persisted to presentday, with mainly oil contributed by both Madbi units and significant amounts of gas from the Meem unit. Therefore, the hydrocarbon exploration processes should be focused on the known kitchen area location of the Late Jurassic Safer, Lam and Meem stratigraphic successions. 


\section{Acknowledgments}

The authors thank the Petroleum Exploration and Production Authority (PEPA), Republic of Yemen for supplying the data for this research. Schlumberger is acknowledged for providing free version of PetroMod Basin Modeling software. The authors also would like to sincerely thank Associate Editor Dr. Qilong Fu and Dr. Balazs Badics as well as an anonymous reviewer for their careful and useful comments that improved the original manuscript.

\section{References}

Abdalla, Y.M., Michael, J.P., William, A.A., James, E.I., Arthur, J.W., 1999. Modeling petroleum generation in the southern Muglad Rift Basin, Sudan. Am. Assoc. Pet. Geol. Bull. 83, 1943-1964.

Alaug, A.S., Leythäeuser, D., Bruns, B., Ahmed, A.F., 2011. Source and reservoir rocks of the Block 18 oilfields, Sabatayn Basin, Yemen: Source rock evaluation, maturation, and reservoir characterization. Iranian Journal of Earth Sciences 3, 134152.

Allen, P.A., Allen, J.R., 1990. Basin Analysis Principles and Applications. Blackwell Scientific Publications, Oxford, pp. 1-642.

As-Saruri, M.A., Sorkhabi, R., Baraba, R., 2010. Sedimentary basins of Yemen: their tectonic development and lithostratigraphic cover. Arabian Journal Geosciences 3, $515-527$.

Behar, F., Vandenbroucke, M., Tang,Y., Marquis, F., Espitalié, J., 1997. Thermal cracking of kerogen in open and closed systems: determination of kinetic 
parameters and stoichiometric coefficients for oil and gas generation. Organic Geochemistry 26, 321-339

Brannin, J., Sahota, Gurdip, Gerdes, K.D., Berry, J.A.L., 1999. Geological evolution of the central Marib--Shabwah basin, Yemen. GeoArabia 4, 9-34.

Beydoun, Z.R., Al-Saruri, M., El-Nakhal, H., Al-Ganad, I.N., Baraba, R.S., Nani, A.S.O., Al- Aawah, M.H., 1998. International Lexicon of Stratigraphy, second ed., vol. III. International Union of Geological Sciences and Ministry of Oil and Mineral Resources, Republic of Yemen, Republic of Yemen, Publication 34, p. 245.

Bordenave, M.L., 1993. Applied Petroleum Geochemistry. Editions Technip, Paris.

Csato, I., A. Habib, K. Kiss, I. Kocz, V. Kovacs, K. Lorincz and K. Milota 2001. Play concepts of oil exploration in Yemen. Oil and Gas Journal, v. 99, p. 68-74.

Espitalié, J., Laporte, J.L., Madec, M., Marquis, F., Leplat, P., Pauletand, J., Boutefeu, A., 1977. Methode rapide de caracterisation des roches meres, de leur potential petrolier et de leu degre d'evolution. Revue de l'Institut Francais du Petrole 32, 23 42.

Hakimi, M.H., Abdullah, W.H., Shalaby, M.R., 2010. Organic geochemistry, burial history and hydrocarbon generation modeling of the Upper Jurassic Madbi Formation, Masila Basin, Yemen. J. Pet. Geol. 33, 299-318.

Hakimi, M.H., Abdullah, W.H., Shalaby, M.R., 2012a. Molecular composition and organic petrographic characterization of Madbi source rocks from the Kharir Oilfield of the Masila Basin (Yemen): palaeoenvironmental and maturity interpretation. Arab J Geosci 5, 817-831 
Hakimi, M.H., Shalaby, M.R., Abdullah, W.H., 2012b. Diagenetic characteristics and reservoir quality of the Lower Cretaceous Biyadh sandstones at Kharir oilfield in the western central Masila Basin, Yemen. Journal of Asian Earth Sciences 51, 109120.

Hakimi, M.H., Abdullah, W.H., 2013a. Organic geochemical characteristics and oil generating potential of the Upper Jurassic Safer shale sediments in the MaribShabowah Basin, western Yemen. Organic Geochemistry 54, 115-124

Hakimi, M.H., Abdullah, W.H., 2013b. Geochemical characteristics of some crude oils from Alif Field in the Marib-Shabowah Basin, and source-related types. Marine and Petroleum Geology 45, 304-314.

Hakimi, M.H., Abdullah, W.H., 2014. Source rock characteristics and hydrocarbon generation modelling of Upper Cretaceous Mukalla Formation in the Jiza-Qamar Basin, Eastern Yemen. Marine and Petroleum Geology 51, 100-116

Hakimi M.H., Abdullah, W.H., 2015. Thermal maturity history and petroleum generation modelling for the Upper Jurassic Madbi source rocks in the Marib-Shabowah Basin, western Yemen. Marine and Petroleum Geology 59, 202-216

Hakimi, M.H., Abdullah, W.H., Shalaby, M.R., Alramisy, G.A., 2014. Geochemistry and organic petrology study of Kimmeridgian organic-rich shales in the MaribShabowah Basin, Yemen: Origin and implication for depositional environments and oil-generation potential. Marine and Petroleum Geology 50, 185-201.

Hunt, J. M., 1995. Petroleum geochemistry and geology: second edition, W. H. Freeman and company, New York. 
He, S., Middleton, M., 2002. Heat flow and thermal maturity modelling in the Northern Carnarvon Basin, North West Shelf, Australia. Mar. Pet. Geol. 19, 1073-1088.

Issler, D.R., Obermajer, M., Reyes, J., Li, M., 2012. Integrated Analysis of Vitrinite Reflectance, Rock-Eval 6, Gas Chromatography, and Gas Chromatography-Mass Spectrometry Data for the Mallik A-06, Parsons N-10 and Kugaluk N-02 Wells, Beaufort-Mackenzie Basin, Northern Canada; Geological Survey of Canada, Open File 6978. http://dx.doi.org/10.4095/289672 (78 pp.).

King, W.A., Mills, B.R., Gardiner, S., Abdillah, A.A., 2003. The Masila Fields, Republic of Yemen. In: Halbouty, M.T. (Ed.), Giant oil and gas fields of the decade 19901999. American Association of Petroleum Geologists Memoir 78, 275-295.

Lachenbruch, A., 1970. Crustal temperature and heat productivity: implications of the linear heat flow relation. J. Geophys. Res. 75, 3291-3300.

Lerche, I., 1990. Basin Analysis: Quantitative Methods. Academic Press, San Diego, p. 562.

Li, M.J., Wang, T.G., Chen, J.F., He, F.Q., Yun, L., Akbar, S., Zhang, W.B., 2010. Paleo heat flow evolution of the Tabei Uplift in Tarim Basin, northwest China. J. Asian Earth Sci. 37, 52-66.

Mckenzie, D., 1978. Some remarks on the development of sedimentary basin. Earth Planet. Sci. Lett. 40, 25-32.

Peters, K.E., 1986. Guidelines for evaluating petroleum source using programmed pyrolysis. AAPG Bull. 70, 318-329. 
Peters, K., Cassa, M., 1994. Applied Source Rock Geochemistry. In Magoon, L.B. and Dow, W. G. eds., 1994, The petroleum system from source to trap: AAPG Memoir $60,93-117$.

Poelchau, H.S., Baker, D.R., Hantschel, Th., Horsfield, B., Wygrala, B., 1997. Basin simulation and the design of the conceptual basin model. In: Welte, D.H., Horsfield, B., Baker, D.R. (Eds.), Petroleum and Basin Evolution. Springer, Berlin e Heidelberg e New York, pp. 5-70.

Redfern, P. and J.A. Jones 1995. The interior basins of Yemen--701 analysis of basin structure and stratigraphy in a regional plate tectonic context. Basin Research, 7, $337-356$.

Sachsenhofer, R.F., Bechtel, A., Dellmour, R.W., Mobarakabad, A.F., Gratzer, R., Salman, A., 2012. Upper Jurassic source rocks in the Sab'atayn Basin, Yemen: Depositional environment, source potential and hydrocarbon generation. GeoArabia $17,161-186$

Shalaby, M.R., Hakimi, M.H., Abdullah, W.H., 2011. Geochemical characteristics and hydrocarbon generation modeling of the Jurassic source rocks in the Shoushan Basin, north Western Desert, Egypt. Marine and Petroleum Geology 28, 16111624.

Shalaby, M.R., Hakimi, M.H., Abdullah, W.H., 2012. Geochemical characterization of solid bitumen (migra bitumen) in the Jurassic sandstone reservoir of the Tut Field, Shushan Basin, northern Western Desert of Egypt. Int. J. Coal Geol. 100, 26-39. 
Shalaby, M.R., Hakimi, M.H., Abdullah, W.H., 2013. Modeling of gas generation from the Alam El-Bueib Formation in the Shoushan Basin, northern western Desert of Egypt. International Journal of Earth Sciences.

Sweeney, J.J., Burnham, A.K., 1990. Evaluation of a simple model of vitrinite reflectance based on chemical kinetics. Am. Assoc. Pet. Geol. Bull. 74, 1559-1570.

Waples, D. W., 1994. Modeling of Sedimentary Basins and Petroleum Systems. In Magoon, L. B. and Dow,W. G. eds., The petroleum system from source to trap: AAPG Memoir 60, pp. 307-322.

Welte, D.H., Yukler, A., 1981. Petroleum origin and accumulation in basin evolution a quantitative model. Am. Assoc. Petr. Geol. Bull. 65, 1387-1396.

Welte, D.H., Yukler, A., 1987. Basin Modeling a new comprehensive method in petroleum geology. Org. Geochem. 13, 141-151.

\section{Figure captions}

Figure 1. Location map of the main sedimentary basins in Republic of Yemen (modified after Beydoun et al., 1998; ), showing location of the Wadi Hajar sub-basin including studied well.

Figure 2. Stratigraphic column for the Wadi Hajar sub-basin based on subsurface exploration wells and pervious published by As-Saruri et al. (2010).

Figure 3. Organic geochemical log of the Late Jurassic-Early Cretaceous source rock samples in the studied well (Mitaq-01) according to Rock-Eval pyrolysis and TOC content results. 
Figure 4. Distribution of total organic carbon (TOC) versus depth (meter) for Late Jurassic-Early Cretaceous formations, showing most of the samples plot in fair to excellent source rocks.

Figure 5. Relationship between (a) total organic matter (TOC) content versus remaining hydrocarbon potential $\left(S_{2}\right)$ and (b) petroleum potential yield (PY) for the analysed Late Jurassic-Early Cretaceous formations.

Figure 6. Plot of hydrogen index $(\mathrm{HI})$ versus pyrolysis $\mathrm{T}_{\max }$, showing kerogen quality of the samples from Late Jurassic-Early Cretaceous formations in the Wadi Hajar sub-basin. Figure 7. Cross-plot of pyrolysis $\mathrm{T}_{\max }$ versus production index (PI), showing the maturation and nature of the hydrocarbon products of the samples from Late JurassicEarly Cretaceous formations in the investigated well (Mintaq-01), Wadi Hajar sub-basin.

Figure 8. Burial history for 1-D model reconstructed for the Mintaq-01well location in the Wadi Hajar sub-basin

Figure 9. (A) Burial and temperature histories reconstructed for the Mintaq-01 well location calibrated to present day corrected bottom-hole temperature data (B).

Figure 10. (A) Burial and thermal maturity histories reconstructed for the Mintaq-01well location calibrated to vitrinite reflectance data (B) using site specific heat flow histories (C).

Figure 11. (a) 1-D model extraction of cumulative hydrocarbon generation and expulsion from the Naifa and Safer source rocks in the Mintaq-01well. (b) Evolution of the transformation ratio through time for the Naifa and Safer source rocks of the same 1D model. 
Figure 12. (a) 1-D model extraction of cumulative hydrocarbon generation and expulsion from the Madbi source rock units (Lam and Meem) in the Mintaq-01well. (b) Evolution of the transformation ratio through time for the Madbi source rock units of the same 1-D model. 


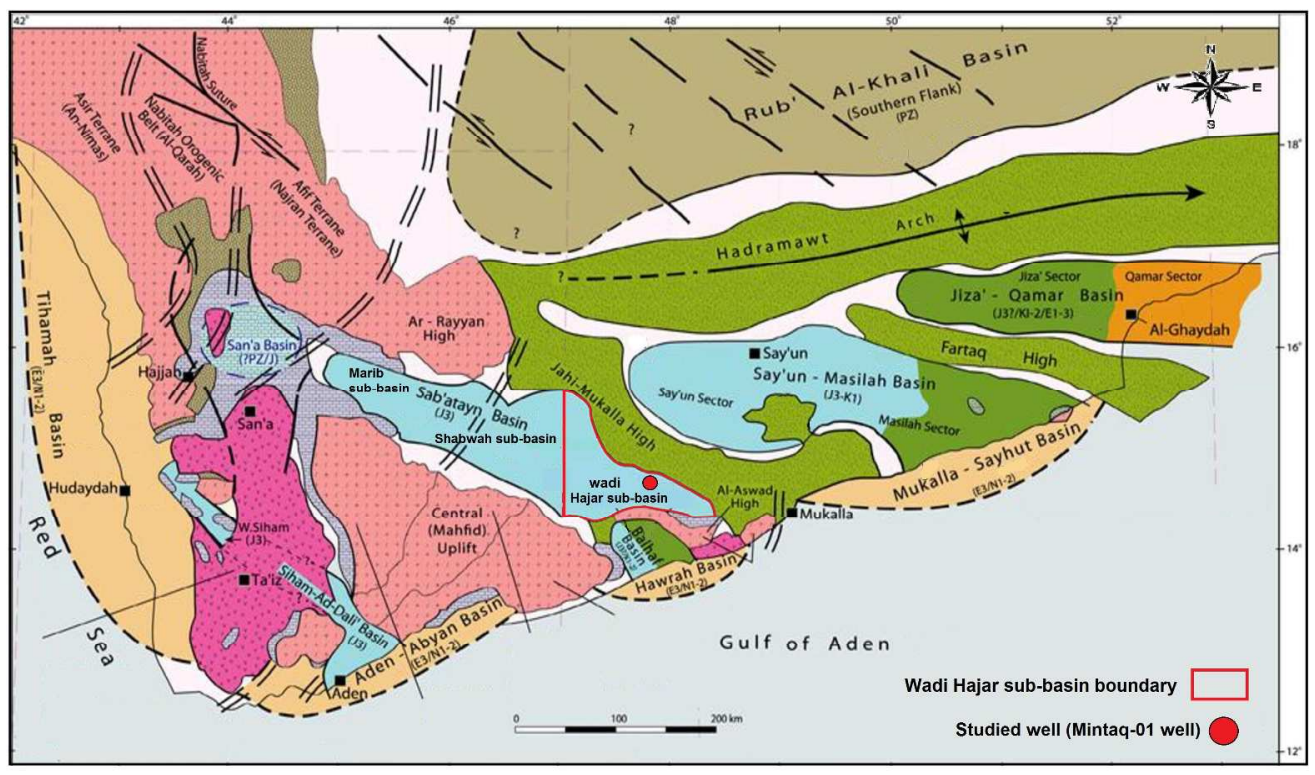

$290 \times 169 \mathrm{~mm}(300 \times 300$ DPI $)$ 


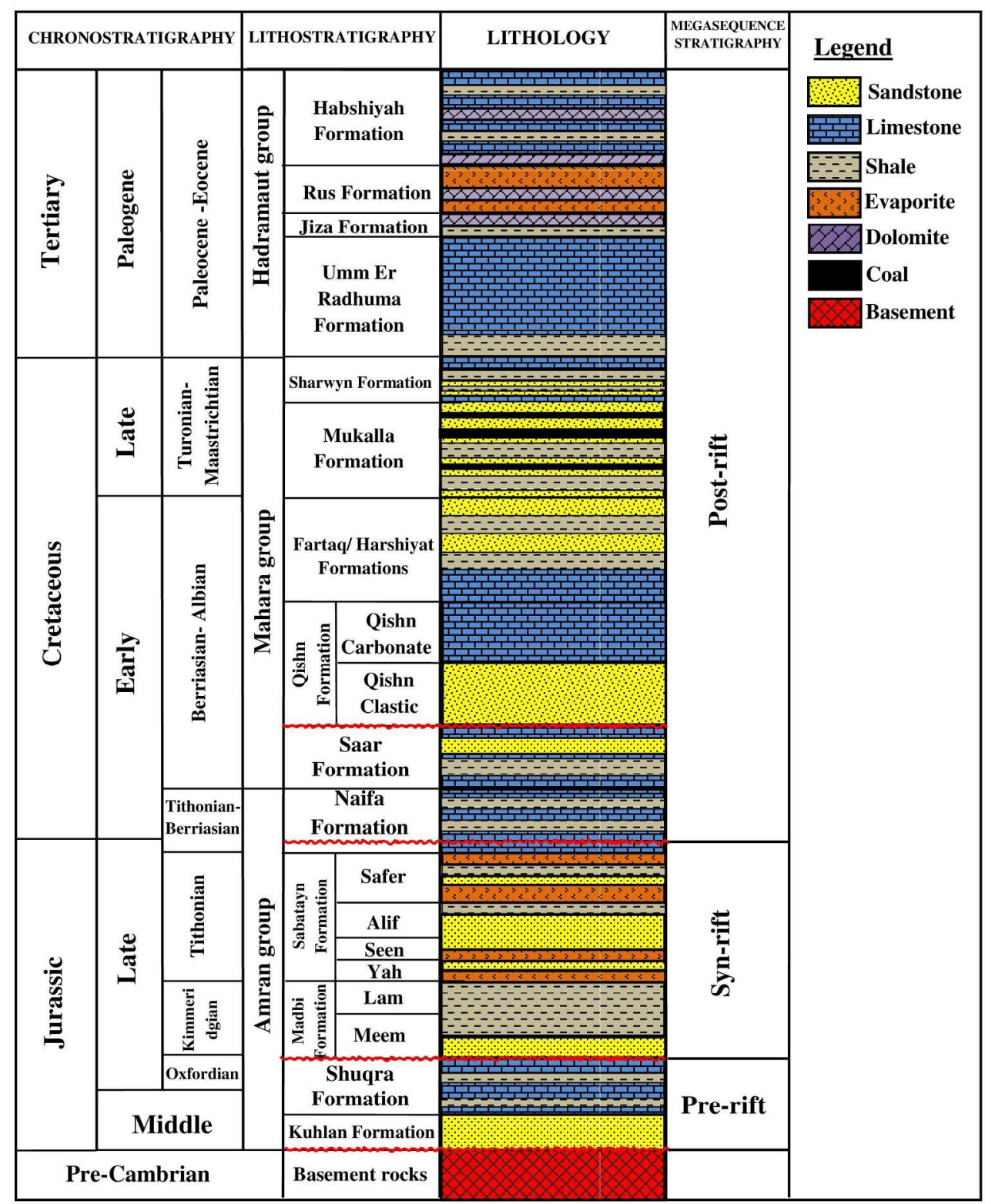

$207 \times 256 \mathrm{~mm}(300 \times 300 \mathrm{DPI})$ 


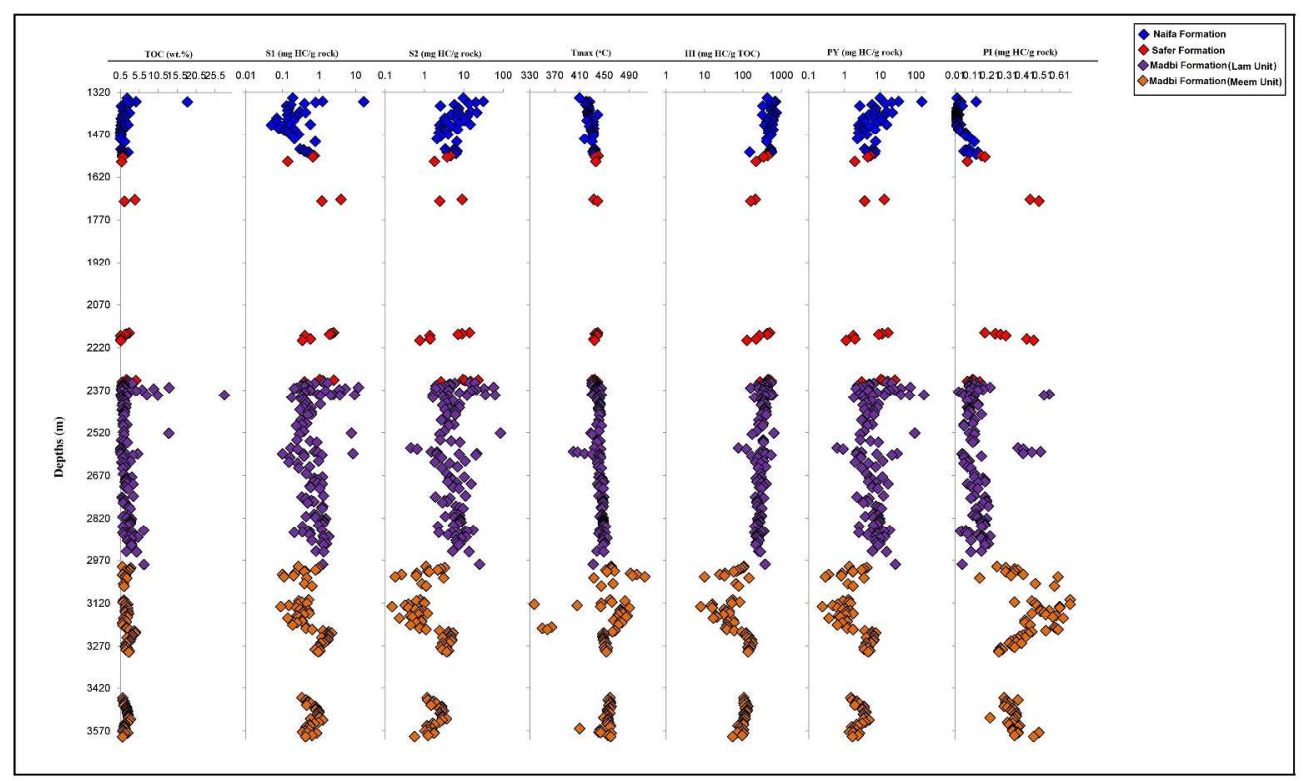

$429 \times 258 \mathrm{~mm}(300 \times 300 \mathrm{DPI})$ 


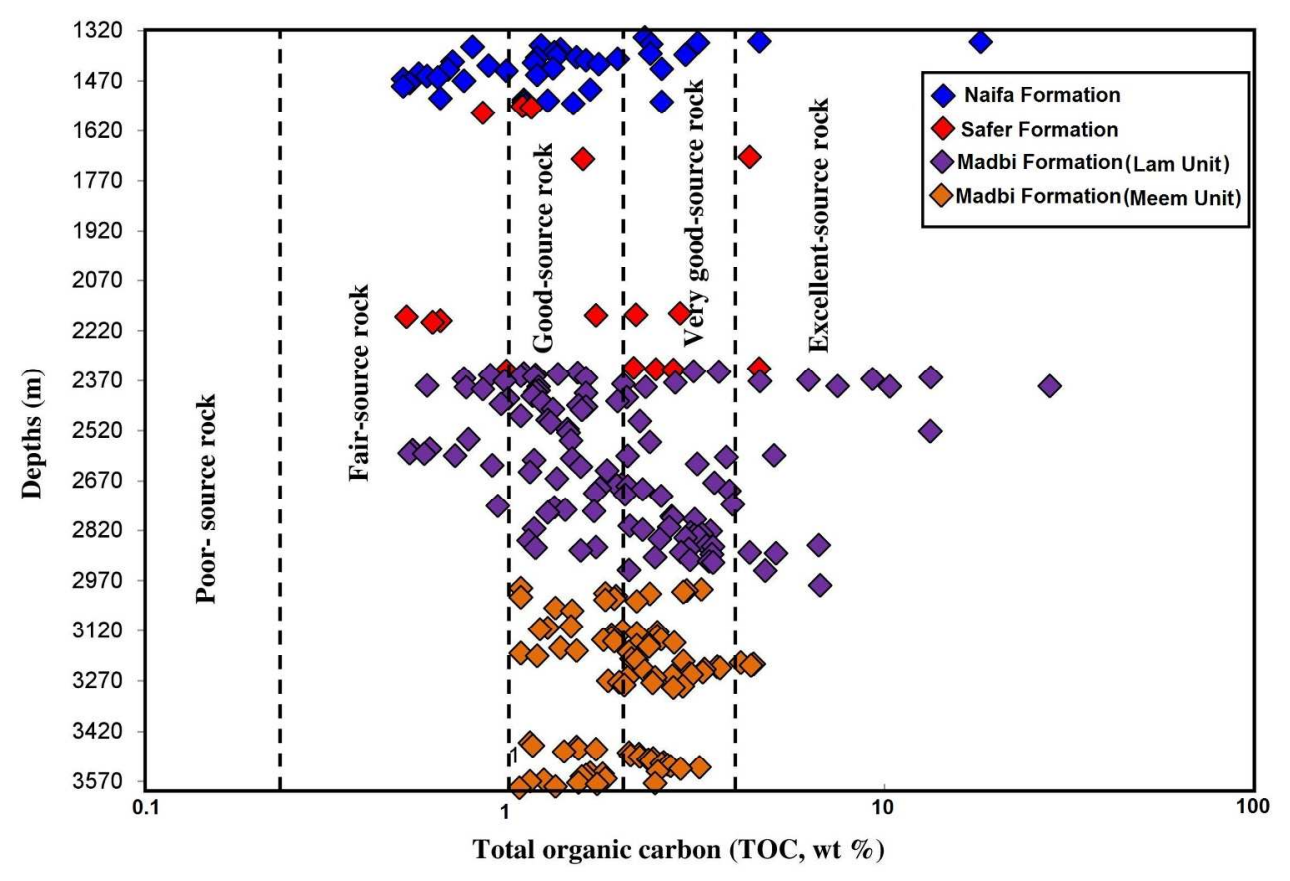

$198 \times 137 m m(300 \times 300$ DPI $)$ 

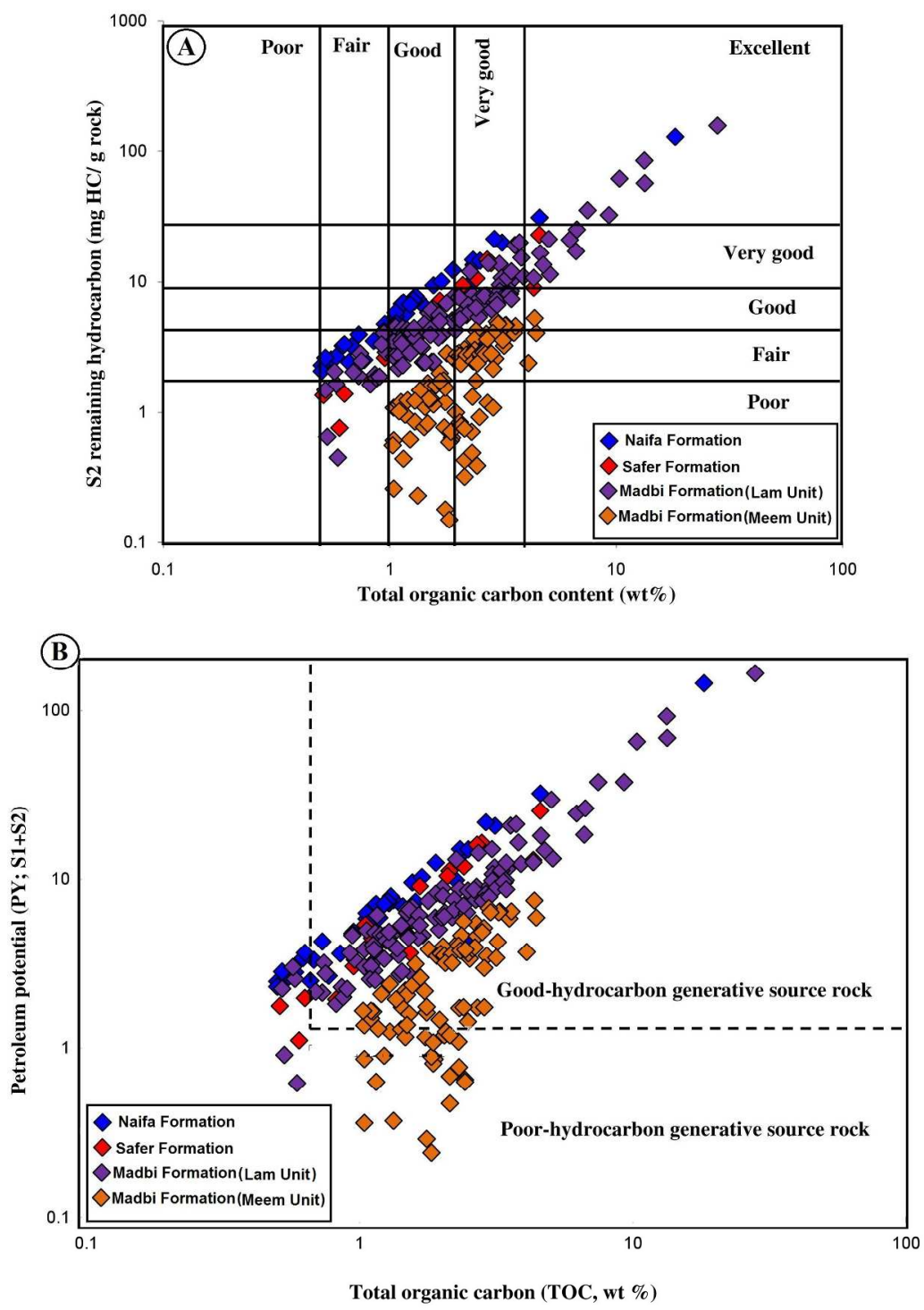

$204 \times 285 \mathrm{~mm}(300 \times 300$ DPI $)$ 


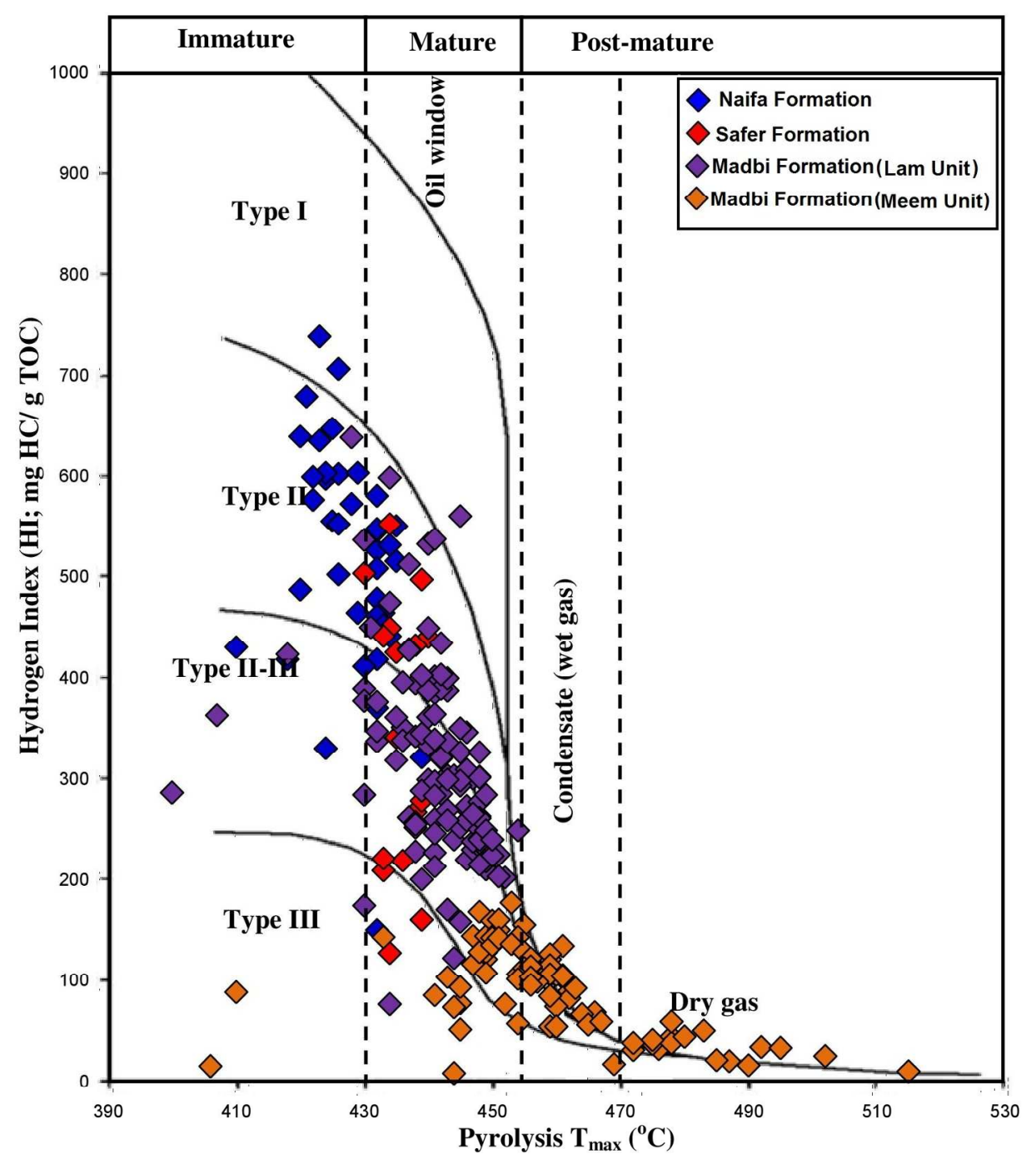

$169 \times 191 \mathrm{~mm}(300 \times 300 \mathrm{DPI})$ 


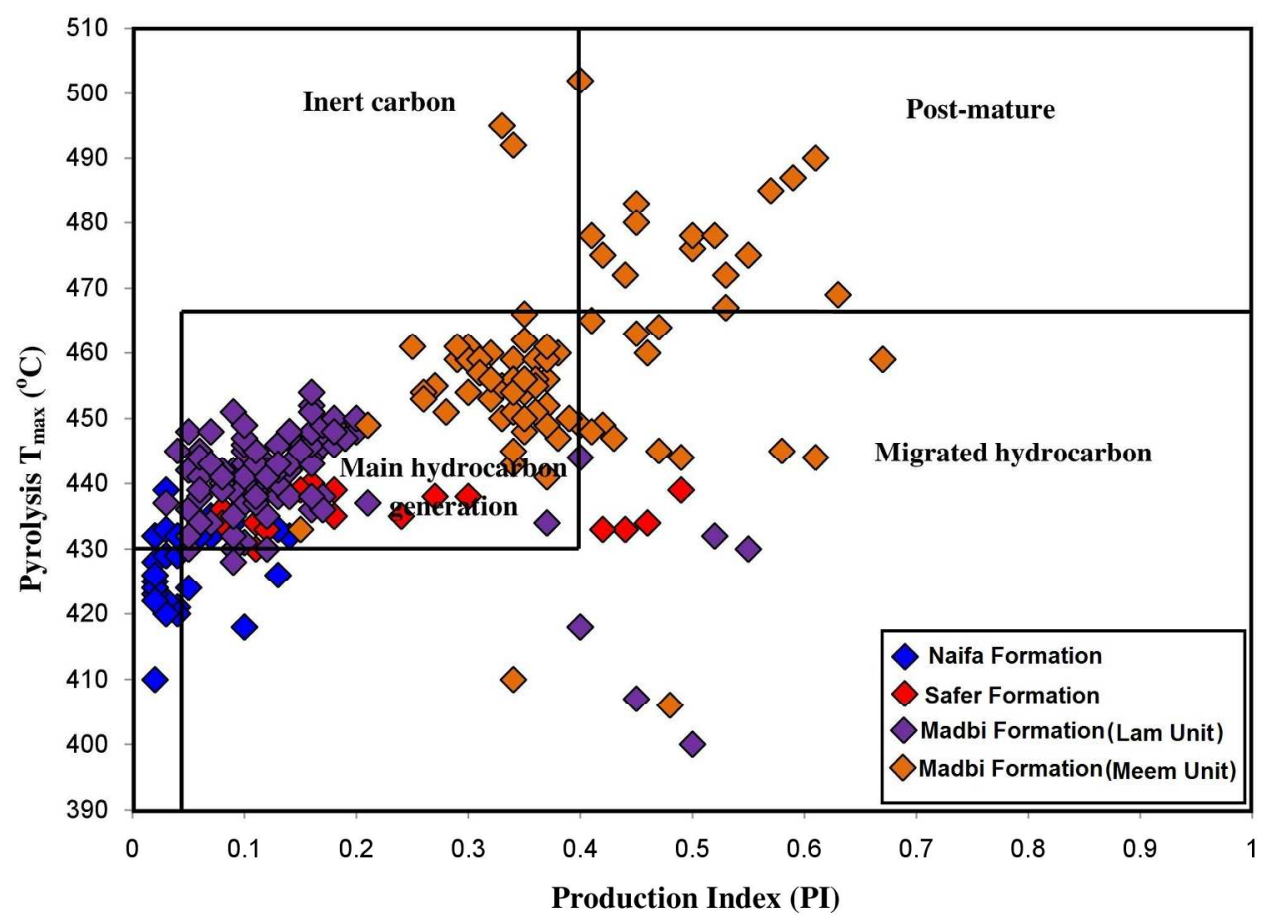

$178 \times 134 \mathrm{~mm}(300 \times 300$ DPI $)$ 


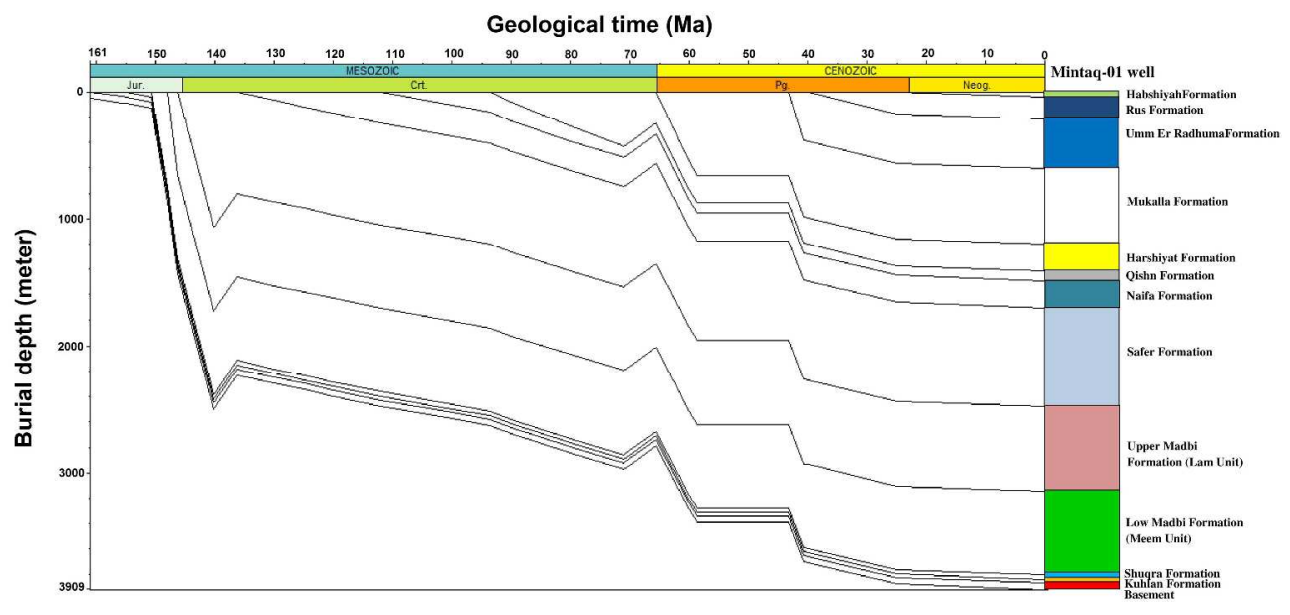

$457 \times 223 \mathrm{~mm}(300 \times 300 \mathrm{DPI})$ 


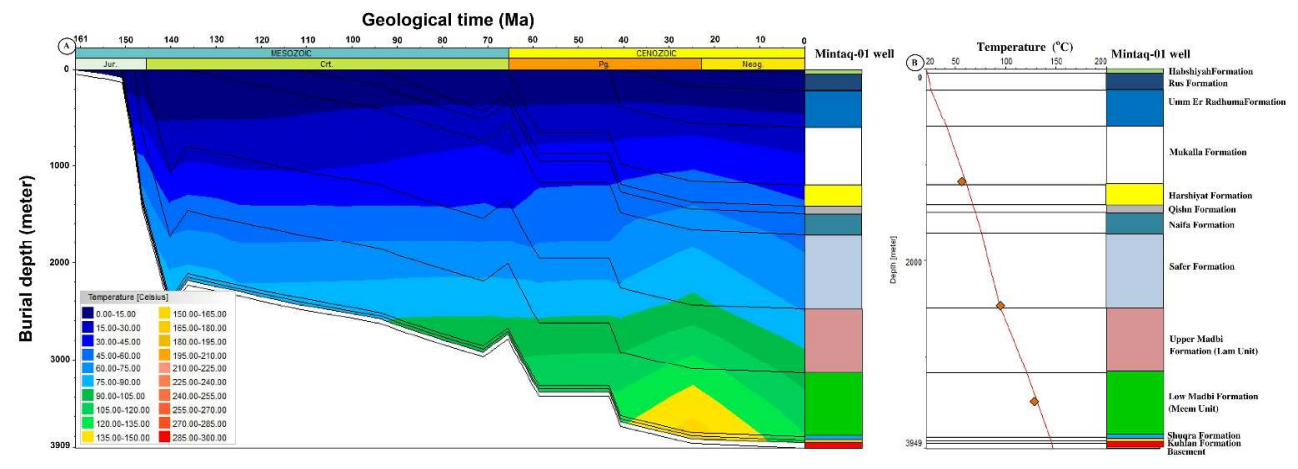

$598 \times 224 \mathrm{~mm}(300 \times 300$ DPI $)$ 


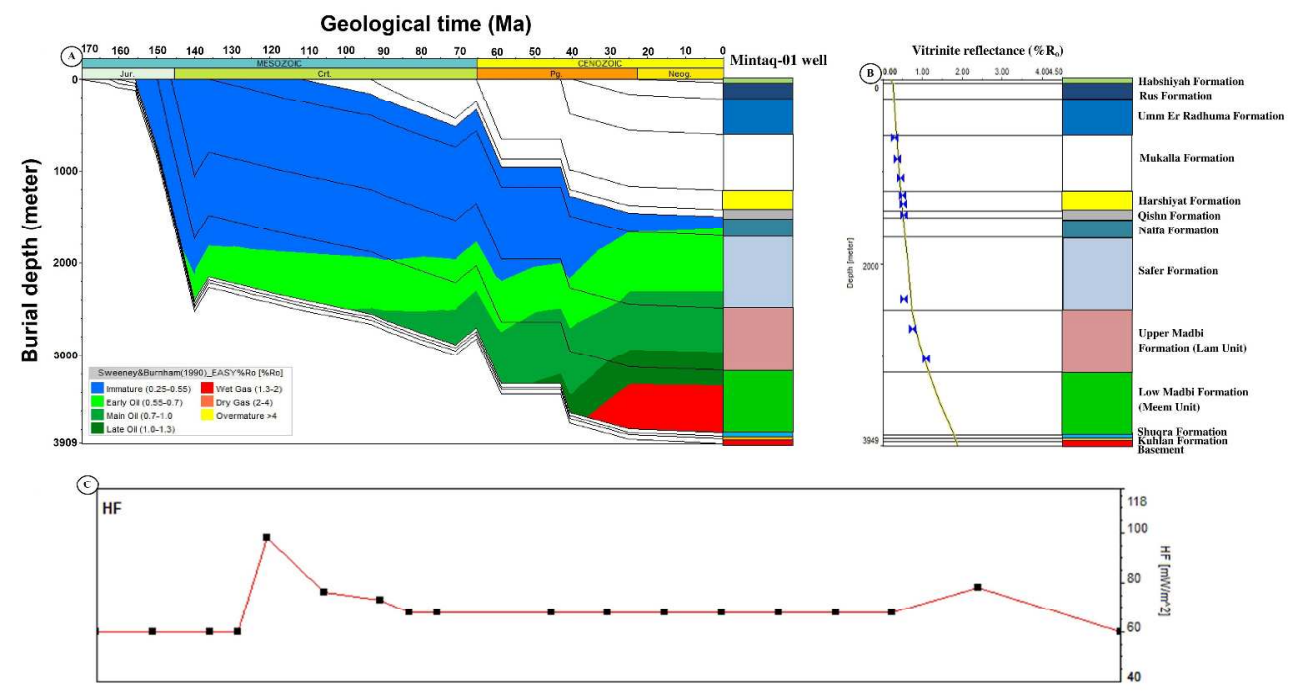

$489 \times 285 \mathrm{~mm}(300 \times 300$ DPI $)$ 

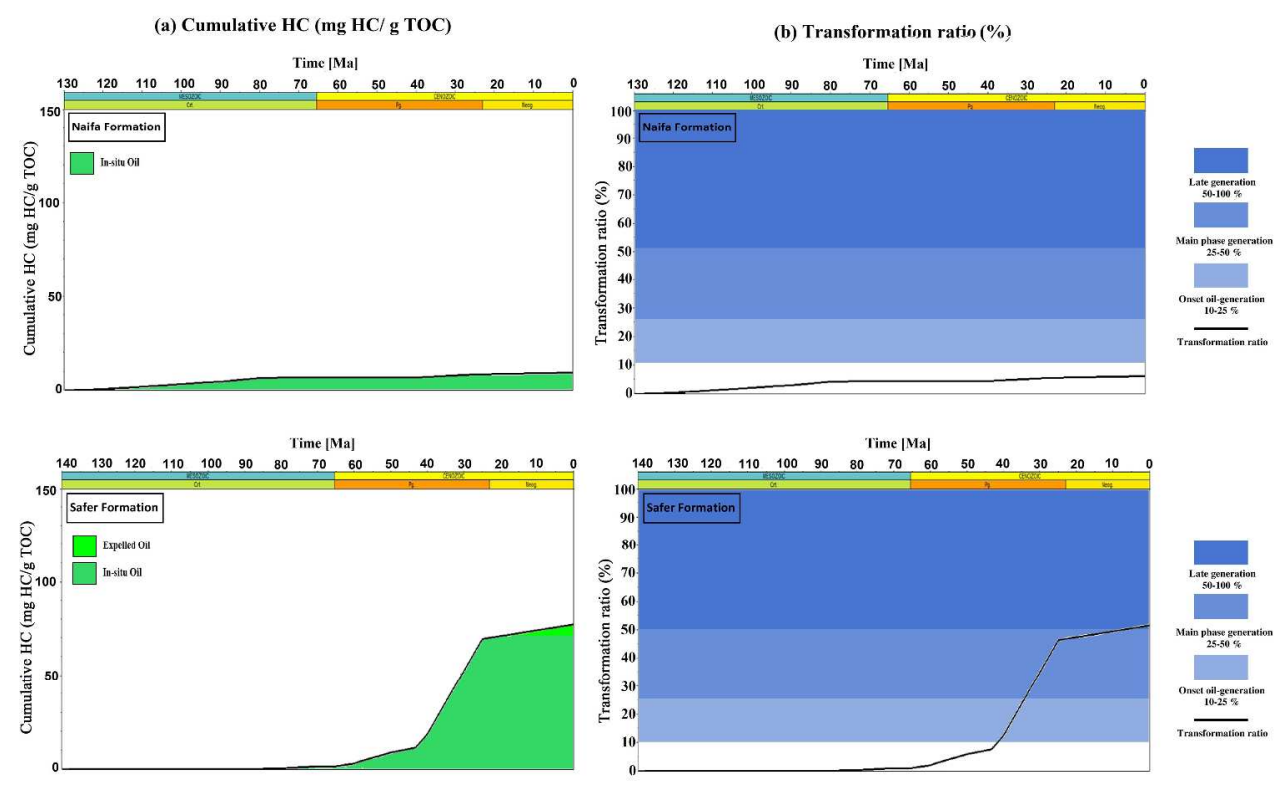

$554 \times 353 \mathrm{~mm}(300 \times 300$ DPI $)$ 
(a) Cumulative $\mathrm{HC}$ (mg HC/g TOC)

(b) Transformation ratio (\%)
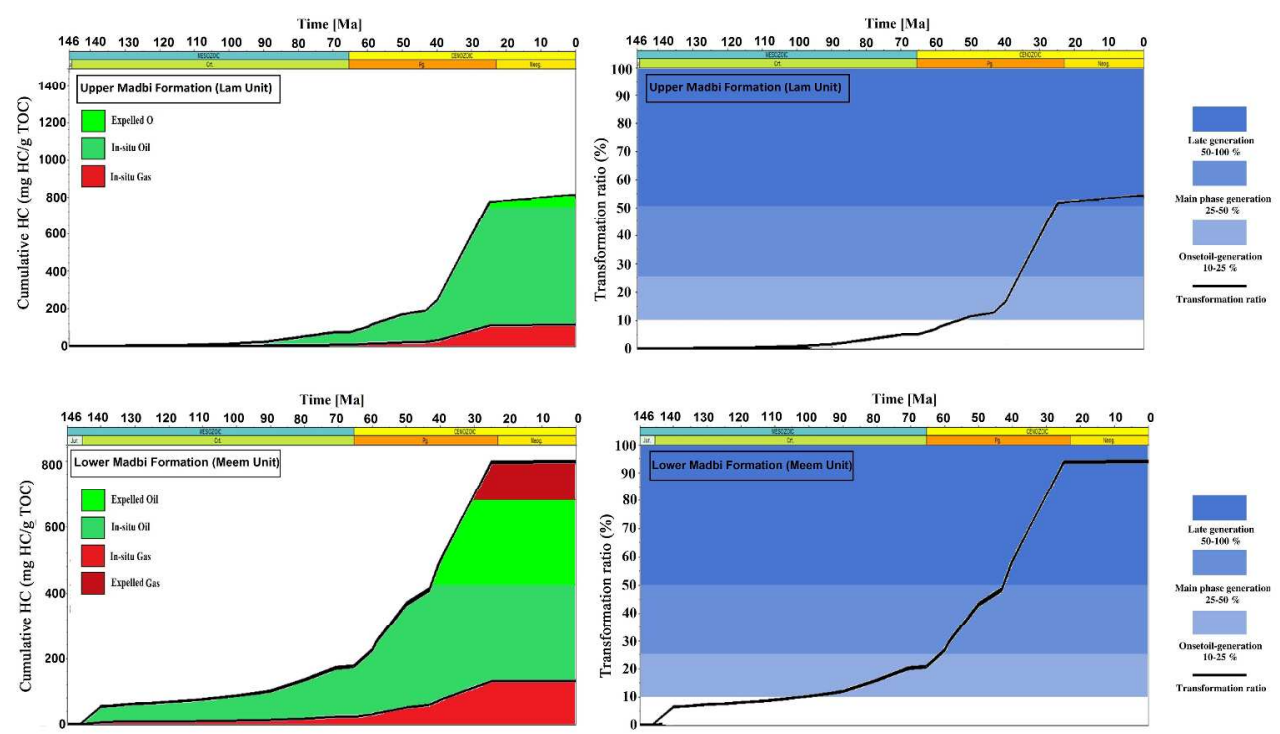

$558 \times 348 \mathrm{~mm}(300 \times 300 \mathrm{DPI})$ 
Table 1

Rock-Eval pyrolysis and TOC content results with calculated parameters of the Late Jurassic-Early Cretaceous source rocks in the Mintaq-01 well of the Wadi Hajar sub-basin, Yemen.

\begin{tabular}{|c|c|c|c|c|c|c|c|c|c|c|c|}
\hline \multirow{2}{*}{ Wells } & \multirow{2}{*}{\multicolumn{2}{|c|}{ Age }} & \multirow{2}{*}{ Formations } & \multirow{2}{*}{ 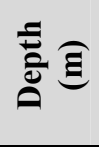 } & \multirow{2}{*}{$\begin{array}{c}\text { TOC } \\
\text { Wt. } \%\end{array}$} & \multicolumn{6}{|c|}{ Rock-Eval pyrolysis } \\
\hline & & & & & & $\begin{array}{c}S_{1} \\
(\mathrm{mg} / \mathrm{g})\end{array}$ & $\begin{array}{c}S_{2} \\
(\mathrm{mg} / \mathrm{g})\end{array}$ & $\begin{array}{l}T_{\max } \\
\left({ }^{\circ} \mathrm{C}\right)\end{array}$ & $\begin{array}{c}\mathbf{H I} \\
(\mathrm{mg} / \mathrm{g})\end{array}$ & $\begin{array}{c}\text { PY } \\
(\mathrm{mg} / \mathrm{g})\end{array}$ & $\begin{array}{c}\text { PI } \\
(\mathrm{mg} / \mathrm{g})\end{array}$ \\
\hline \multirow{40}{*}{ 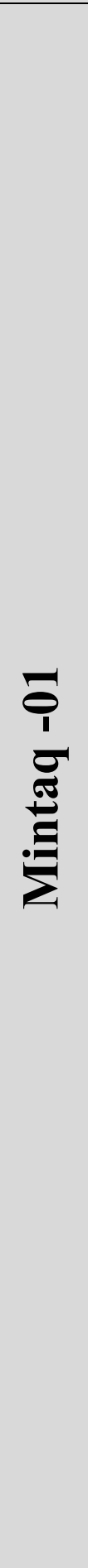 } & \multirow{40}{*}{ 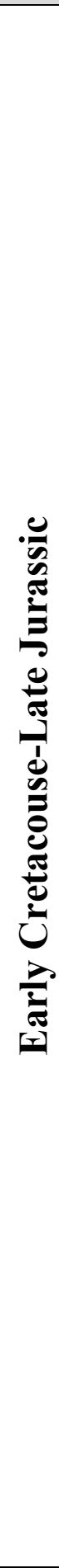 } & \multirow{40}{*}{ 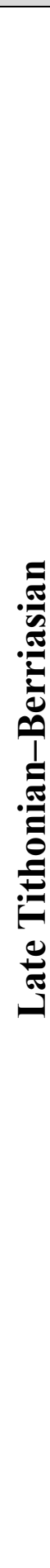 } & \multirow{40}{*}{ 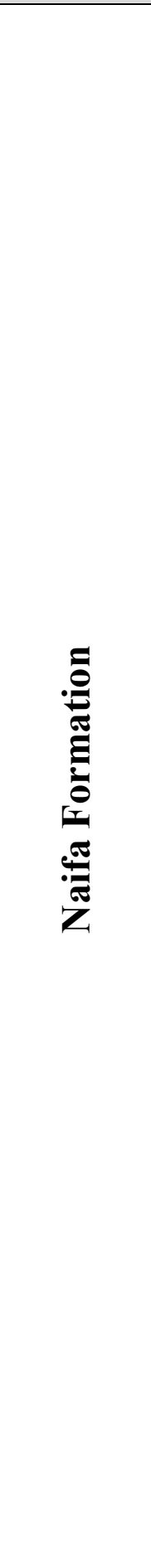 } & 1340 & 2.25 & 0.19 & 9.68 & 410 & 430 & 9.87 & 0.02 \\
\hline & & & & 1352 & 4.59 & 1.25 & 31.17 & 421 & 679 & 32.42 & 0.04 \\
\hline & & & & 1353 & 18.22 & 16.72 & 128.63 & 426 & 706 & 145.35 & 0.13 \\
\hline & & & & 1356 & 3.13 & 0.80 & 20.00 & 420 & 639 & 20.80 & 0.04 \\
\hline & & & & 1360 & 2.34 & 0.40 & 13.48 & 422 & 576 & 13.88 & 0.03 \\
\hline & & & & 1364 & 1.18 & 0.17 & 5.75 & 420 & 487 & 5.92 & 0.03 \\
\hline & & & & 1368 & 0.77 & 0.13 & 2.54 & 424 & 330 & 2.67 & 0.05 \\
\hline & & & & 1376 & 1.33 & 0.15 & 7.38 & 425 & 555 & 7.53 & 0.02 \\
\hline & & & & 1384 & 1.28 & 0.14 & 7.07 & 426 & 552 & 7.21 & 0.02 \\
\hline & & & & 1388 & 2.33 & 0.30 & 14.80 & 423 & 635 & 15.10 & 0.02 \\
\hline & & & & 1392 & 2.90 & 0.43 & 21.40 & 423 & 738 & 21.83 & 0.02 \\
\hline & & & & 1396 & 1.30 & 0.16 & 7.76 & 424 & 597 & 7.92 & 0.02 \\
\hline & & & & 1399 & 1.47 & 0.14 & 4.72 & 439 & 321 & 4.86 & 0.03 \\
\hline & & & & 1400 & 1.15 & 0.14 & 6.87 & 424 & 597 & 7.01 & 0.02 \\
\hline & & & & 1404 & 1.90 & 0.25 & 12.29 & 425 & 647 & 12.54 & 0.02 \\
\hline & & & & 1408 & 1.56 & 0.19 & 9.39 & 426 & 602 & 9.58 & 0.02 \\
\hline & & & & 1412 & 0.68 & 0.07 & 3.25 & 432 & 478 & 3.32 & 0.02 \\
\hline & & & & 1416 & 1.13 & 0.14 & 6.81 & 424 & 603 & 6.95 & 0.02 \\
\hline & & & & 1420 & 1.69 & 0.20 & 10.12 & 422 & 599 & 10.32 & 0.02 \\
\hline & & & & 1424 & 0.85 & 0.07 & 3.55 & 432 & 418 & 3.62 & 0.02 \\
\hline & & & & 1432 & 1.27 & 0.15 & 7.26 & 428 & 572 & 7.41 & 0.02 \\
\hline & & & & 1434 & 2.50 & 0.58 & 14.50 & 432 & 580 & 15.08 & 0.04 \\
\hline & & & & 1436 & 0.66 & 0.05 & 2.44 & 432 & 370 & 2.49 & 0.02 \\
\hline & & & & 1440 & 0.95 & 0.10 & 4.77 & 426 & 502 & 4.87 & 0.02 \\
\hline & & & & 1448 & 0.55 & 0.08 & 2.55 & 433 & 464 & 2.63 & 0.03 \\
\hline & & & & 1452 & 1.15 & 0.21 & 6.93 & 429 & 603 & 7.14 & 0.03 \\
\hline & & & & 1456 & 0.58 & 0.11 & 2.69 & 429 & 464 & 2.80 & 0.04 \\
\hline & & & & 1460 & 0.62 & 0.13 & 3.26 & 432 & 526 & 3.39 & 0.04 \\
\hline & & & & 1464 & 0.50 & 0.16 & 2.31 & 432 & 461 & 2.47 & 0.07 \\
\hline & & & & 1470 & 0.73 & 0.28 & 3.98 & 432 & 545 & 4.26 & 0.07 \\
\hline & & & & 1476 & 0.52 & 0.18 & 2.64 & 432 & 508 & 2.82 & 0.07 \\
\hline & & & & 1486 & 0.50 & 0.21 & 2.09 & 418 & 418 & 2.30 & 0.10 \\
\hline & & & & 1496 & 1.60 & 0.79 & 6.58 & 430 & 411 & 7.37 & 0.12 \\
\hline & & & & 1522 & 0.63 & 0.30 & 3.35 & 434 & 531 & 3.65 & 0.09 \\
\hline & & & & 1526 & 1.06 & 0.38 & 5.46 & 435 & 515 & 5.84 & 0.07 \\
\hline & & & & 1530 & 1.23 & 0.40 & 6.73 & 432 & 547 & 7.13 & 0.06 \\
\hline & & & & 1533 & 2.50 & 0.53 & 3.75 & 432 & 150 & 4.28 & 0.14 \\
\hline & & & & 1534 & 1.06 & 0.47 & 5.83 & 435 & 550 & 6.30 & 0.08 \\
\hline & & & & 1538 & 1.44 & 0.57 & 6.35 & 434 & 441 & 6.92 & 0.09 \\
\hline & & & & 1541 & 1.07 & 0.63 & 4.84 & 433 & 452 & 5.47 & 0.13 \\
\hline
\end{tabular}




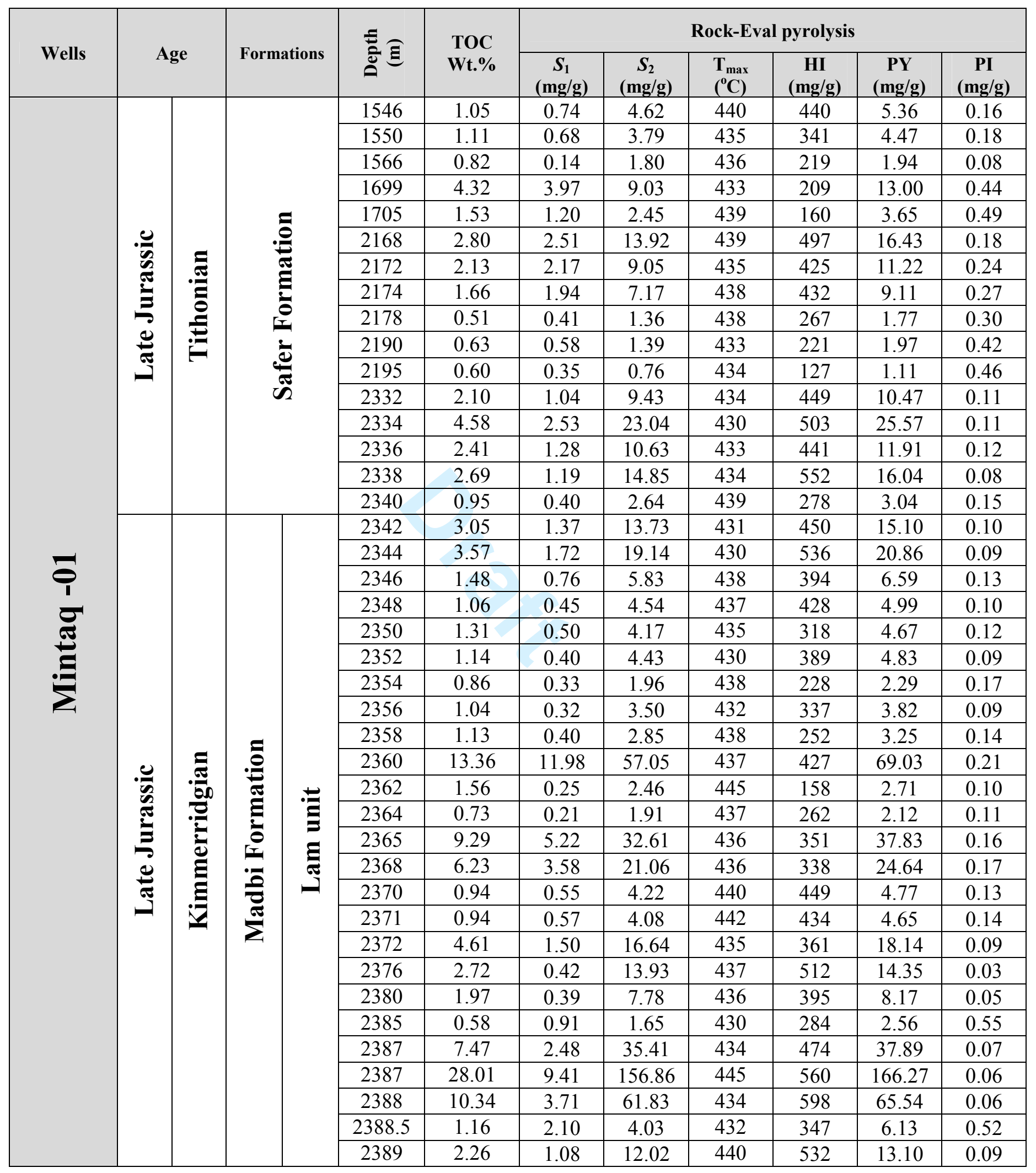




\begin{tabular}{|c|c|c|c|c|c|c|c|c|c|c|c|c|}
\hline \multirow{2}{*}{ Wells } & \multirow{2}{*}{\multicolumn{2}{|c|}{ Age }} & \multirow{2}{*}{\multicolumn{2}{|c|}{ Formations }} & \multirow{3}{*}{ 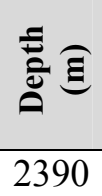 } & \multirow{3}{*}{$\begin{array}{c}\begin{array}{c}\text { TOC } \\
\text { Wt.\% }\end{array} \\
0.74 \\
\end{array}$} & \multicolumn{6}{|c|}{ Rock-Eval pyrolysis } \\
\hline & & & & & & & \multirow{2}{*}{$\begin{array}{c}\begin{array}{c}\boldsymbol{S}_{1} \\
(\mathrm{mg} / \mathrm{g})\end{array} \\
0.34 \\
\end{array}$} & \multirow{2}{*}{$\begin{array}{c}\begin{array}{c}\boldsymbol{S}_{\mathbf{2}} \\
(\mathbf{m g} / \mathbf{g})\end{array} \\
2.85\end{array}$} & \multirow{2}{*}{$\begin{array}{l}\mathbf{T}_{\max } \\
\left({ }^{\circ} \mathbf{C}\right)\end{array}$} & \multirow{2}{*}{$\begin{array}{c}\begin{array}{c}\text { HI } \\
(\mathbf{m g} / \mathbf{g})\end{array} \\
385 \\
\end{array}$} & \multirow{2}{*}{$\begin{array}{c}\begin{array}{c}\text { PY } \\
(\mathrm{mg} / \mathrm{g})\end{array} \\
3.19 \\
\end{array}$} & \multirow{2}{*}{$\begin{array}{c}\begin{array}{c}\text { PI } \\
(\mathrm{mg} / \mathbf{g})\end{array} \\
0.12 \\
\end{array}$} \\
\hline \multirow{43}{*}{ 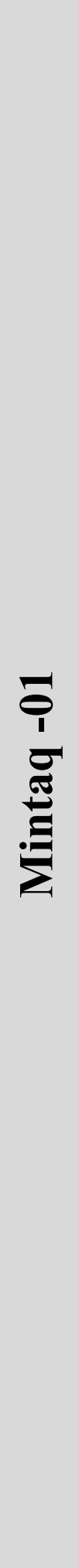 } & \multirow{43}{*}{ 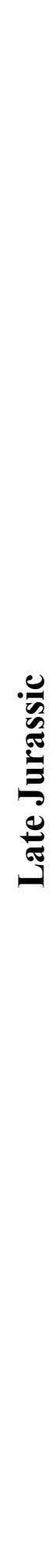 } & & & & & & & & & & & \\
\hline & & \multirow{42}{*}{ } & \multirow{42}{*}{ 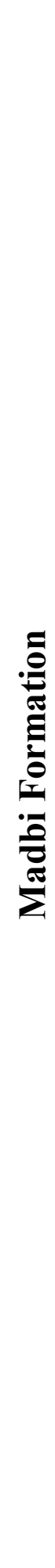 } & \multirow{42}{*}{ 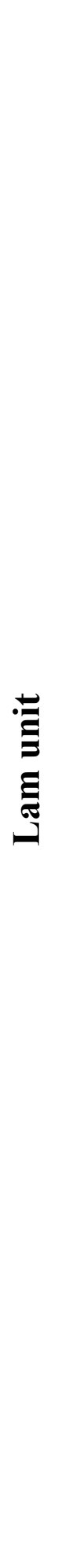 } & 2396 & 0.82 & 0.18 & 1.64 & 439 & 200 & 1.82 & 0.11 \\
\hline & & & & & 2400 & 1.16 & 0.37 & 3.71 & 442 & 320 & 4.08 & 0.10 \\
\hline & & & & & 2404 & 1.14 & 0.34 & 3.41 & 440 & 299 & 3.75 & 0.10 \\
\hline & & & & & 2408 & 1.56 & 0.42 & 5.30 & 439 & 340 & 5.72 & 0.08 \\
\hline & & & & & 2416 & 1.12 & 0.47 & 3.60 & 442 & 321 & 4.07 & 0.13 \\
\hline & & & & & 2420 & 2.01 & 1.09 & 7.78 & 443 & 387 & 8.87 & 0.14 \\
\hline & & & & & 2424 & 0.96 & 0.41 & 2.91 & 443 & 303 & 3.32 & 0.14 \\
\hline & & & & & 2432 & 1.90 & 0.61 & 7.62 & 441 & 401 & 8.23 & 0.08 \\
\hline & & & & & 2436 & 1.19 & 0.39 & 4.30 & 440 & 361 & 4.69 & 0.09 \\
\hline & & & & & 2440 & 0.92 & 0.30 & 3.35 & 441 & 364 & 3.65 & 0.09 \\
\hline & & & & & 2444 & 1.49 & 0.52 & 5.80 & 442 & 389 & 6.32 & 0.09 \\
\hline & & & & & 2448 & 1.56 & 0.62 & 6.22 & 443 & 399 & 6.84 & 0.10 \\
\hline & & & & & 2456 & 1.27 & 0.62 & 3.85 & 444 & 303 & 4.47 & 0.16 \\
\hline & & & & & 2458 & 1.52 & 0.49 & 6.13 & 442 & 403 & 6.62 & 0.08 \\
\hline & & & & & 2476 & 1.04 & 0.32 & 2.70 & 441 & 260 & 3.02 & 0.12 \\
\hline & & & & & 2488 & 1.23 & 0.46 & 4.17 & 440 & 339 & 4.63 & 0.11 \\
\hline & & & & & 2492 & 2.18 & 0.34 & 5.60 & 438 & 257 & 5.94 & 0.06 \\
\hline & & & & & 2496 & 1.25 & 0.24 & 4.08 & 445 & 326 & 4.32 & 0.06 \\
\hline & & & & & 2516 & 1.39 & 0.38 & 3.16 & 441 & 227 & 3.54 & 0.12 \\
\hline & & & & & 2522 & 13.31 & 7.64 & 84.92 & 428 & 638 & 92.56 & 0.09 \\
\hline & & & & & 2526 & 1.40 & 0.29 & 2.44 & 430 & 174 & 2.73 & 0.12 \\
\hline & & & & & 2546 & 0.75 & 0.25 & 2.50 & 440 & 333 & 2.75 & 0.10 \\
\hline & & & & & 2550 & 1.42 & 0.57 & 4.77 & 443 & 336 & 5.34 & 0.12 \\
\hline & & & & & 2554 & 2.32 & 0.87 & 7.93 & 438 & 342 & 8.80 & 0.11 \\
\hline & & & & & 2574 & 0.59 & 0.17 & 0.45 & 434 & 76 & 0.62 & 0.37 \\
\hline & & & & & 2578 & 0.53 & 0.26 & 0.65 & 444 & 122 & 0.91 & 0.40 \\
\hline & & & & & 2587 & 0.52 & 0.75 & 1.49 & 400 & 286 & 2.24 & 0.50 \\
\hline & & & & & 2589 & 0.57 & 0.93 & 2.07 & 407 & 363 & 3.00 & 0.45 \\
\hline & & & & & 2594 & 5.03 & 8.51 & 21.28 & 418 & 423 & 29.79 & 0.40 \\
\hline & & & & & 2595 & 0.69 & 0.10 & 2.05 & 442 & 297 & 2.15 & 0.05 \\
\hline & & & & & 2596 & 2.02 & 0.38 & 7.62 & 430 & 377 & 8.00 & 0.05 \\
\hline & & & & & 2599 & 3.74 & 1.20 & 20.08 & 441 & 537 & 21.28 & 0.06 \\
\hline & & & & & 2603 & 1.43 & 0.39 & 2.43 & 443 & 170 & 2.82 & 0.16 \\
\hline & & & & & 2608 & 1.13 & 0.16 & 2.71 & 444 & 240 & 2.87 & 0.06 \\
\hline & & & & & 2620 & 3.12 & 0.97 & 10.76 & 439 & 345 & 11.73 & 0.09 \\
\hline & & & & & 2624 & 0.87 & 0.15 & 1.85 & 441 & 213 & 2.00 & 0.08 \\
\hline & & & & & 2628 & 1.51 & 0.26 & 4.35 & 439 & 288 & 4.61 & 0.06 \\
\hline & & & & & 2640 & 1.78 & 0.55 & 6.89 & 440 & 387 & 7.44 & 0.08 \\
\hline & & & & & 2644 & 1.10 & 0.28 & 2.77 & 445 & 252 & 3.05 & 0.10 \\
\hline & & & & & 2664 & 1.30 & 0.45 & 3.71 & 442 & 285 & 4.16 & 0.12 \\
\hline & & & & & 2676 & 3.47 & 1.24 & 10.31 & 441 & 297 & 11.55 & 0.12 \\
\hline & & & & & 2680 & 1.95 & 0.73 & 4.29 & 446 & 220 & 5.02 & 0.17 \\
\hline
\end{tabular}




\begin{tabular}{|c|c|c|c|c|c|c|c|c|c|c|c|c|}
\hline \multirow{2}{*}{ Wells } & \multirow{2}{*}{\multicolumn{2}{|c|}{ Age }} & \multirow{2}{*}{\multicolumn{2}{|c|}{ Formations }} & \multirow{2}{*}{ 离国 } & \multirow{2}{*}{$\begin{array}{c}\text { TOC } \\
\text { Wt. } \%\end{array}$} & \multicolumn{6}{|c|}{ Rock-Eval pyrolysis } \\
\hline & & & & & & & $\begin{array}{c}S_{1} \\
(\mathrm{mg} / \mathrm{g})\end{array}$ & $\begin{array}{c}S_{2} \\
(\mathrm{mg} / \mathrm{g})\end{array}$ & $\begin{array}{l}T_{\max } \\
\left({ }^{\circ} \mathrm{C}\right)\end{array}$ & $\underset{(\mathrm{HI} / \mathrm{g})}{\mathbf{H I}}$ & $\begin{array}{c}\text { PY } \\
(\mathrm{mg} / \mathrm{g})\end{array}$ & $\begin{array}{c}\mathbf{P I} \\
(\mathrm{mg} / \mathrm{g})\end{array}$ \\
\hline \multirow{47}{*}{ 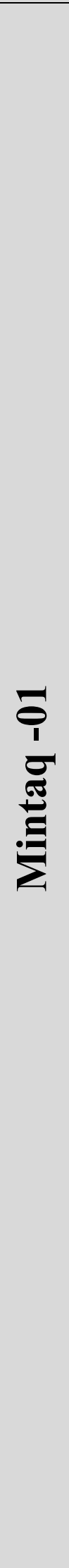 } & \multirow{47}{*}{ 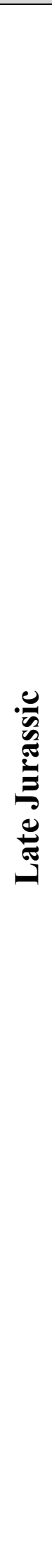 } & \multirow{47}{*}{ 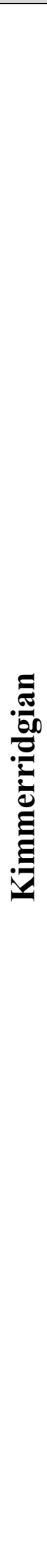 } & \multirow{47}{*}{ 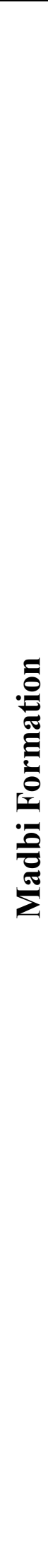 } & \multirow{47}{*}{ 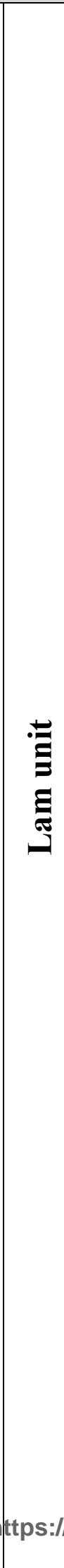 } & 2684 & 1.89 & 0.82 & 5.10 & 446 & 270 & 5.92 & 0.16 \\
\hline & & & & & 2686 & 2.02 & 0.94 & 5.23 & 446 & 259 & 6.17 & 0.18 \\
\hline & & & & & 2692 & 1.70 & 0.71 & 3.93 & 449 & 231 & 4.64 & 0.18 \\
\hline & & & & & 2696 & 2.22 & 0.93 & 6.66 & 447 & 300 & 7.59 & 0.14 \\
\hline & & & & & 2700 & 3.81 & 1.23 & 15.32 & 439 & 402 & 16.55 & 0.08 \\
\hline & & & & & 2708 & 1.65 & 0.56 & 5.59 & 441 & 339 & 6.15 & 0.10 \\
\hline & & & & & 2712 & 1.99 & 0.59 & 5.35 & 443 & 269 & 5.94 & 0.11 \\
\hline & & & & & 2716 & 2.49 & 1.05 & 7.52 & 448 & 302 & 8.57 & 0.14 \\
\hline & & & & & 2742 & 3.89 & 1.32 & 11.01 & 441 & 283 & 12.33 & 0.12 \\
\hline & & & & & 2746 & 0.90 & 0.34 & 1.89 & 449 & 210 & 2.23 & 0.18 \\
\hline & & & & & 2750 & 1.28 & 0.44 & 4.43 & 446 & 346 & 4.87 & 0.10 \\
\hline & & & & & 2758 & 1.37 & 0.62 & 3.26 & 447 & 238 & 3.88 & 0.19 \\
\hline & & & & & 2762 & 1.64 & 0.72 & 3.77 & 447 & 230 & 4.49 & 0.19 \\
\hline & & & & & 2766 & 1.23 & 0.49 & 2.87 & 448 & 233 & 3.36 & 0.17 \\
\hline & & & & & 2778 & 2.66 & 1.26 & 6.30 & 448 & 237 & 7.56 & 0.20 \\
\hline & & & & & 2782 & 2.68 & 1.18 & 7.85 & 445 & 293 & 9.03 & 0.15 \\
\hline & & & & & 2786 & 3.07 & 1.23 & 9.49 & 446 & 309 & 10.72 & 0.13 \\
\hline & & & & & 2806 & 2.05 & 0.73 & 5.60 & 446 & 273 & 6.33 & 0.13 \\
\hline & & & & & 2810 & 2.62 & 0.86 & 7.81 & 445 & 298 & 8.67 & 0.11 \\
\hline & & & & & 2814 & 1.13 & 0.44 & 3.38 & 443 & 299 & 3.82 & 0.13 \\
\hline & & & & & 2818 & 2.22 & 0.81 & 5.79 & 448 & 261 & 6.60 & 0.14 \\
\hline & & & & & 2822 & 3.39 & 1.53 & 8.07 & 447 & 238 & 9.60 & 0.19 \\
\hline & & & & & 2826 & 2.99 & 1.26 & 7.86 & 448 & 263 & 9.12 & 0.16 \\
\hline & & & & & 2830 & 3.21 & 1.37 & 8.03 & 448 & 250 & 9.40 & 0.17 \\
\hline & & & & & 2834 & 3.06 & 1.36 & 8.48 & 448 & 277 & 9.84 & 0.16 \\
\hline & & & & & 2838 & 3.14 & 1.21 & 7.57 & 448 & 241 & 8.78 & 0.16 \\
\hline & & & & & 2842 & 2.90 & 1.25 & 6.96 & 448 & 240 & 8.21 & 0.18 \\
\hline & & & & & 2846 & 2.47 & 0.97 & 5.38 & 449 & 218 & 6.35 & 0.18 \\
\hline & & & & & 2850 & 1.09 & 0.35 & 2.20 & 452 & 202 & 2.55 & 0.16 \\
\hline & & & & & 2864 & 6.64 & 1.20 & 17.20 & 443 & 259 & 18.40 & 0.07 \\
\hline & & & & & 2866 & 3.30 & 0.54 & 10.76 & 448 & 326 & 11.30 & 0.05 \\
\hline & & & & & 2868 & 3.44 & 0.48 & 12.04 & 445 & 350 & 12.52 & 0.04 \\
\hline & & & & & 2870 & 1.66 & 0.35 & 5.00 & 448 & 301 & 5.35 & 0.07 \\
\hline & & & & & 2872 & 1.14 & 0.21 & 2.31 & 451 & 203 & 2.52 & 0.09 \\
\hline & & & & & 2876 & 2.96 & 0.58 & 7.28 & 441 & 246 & 7.86 & 0.08 \\
\hline & & & & & 2880 & 1.51 & 0.55 & 3.94 & 448 & 261 & 4.49 & 0.14 \\
\hline & & & & & 2885 & 2.82 & 1.29 & 6.15 & 449 & 218 & 7.44 & 0.21 \\
\hline & & & & & 2886 & 4.32 & 1.83 & 10.76 & 449 & 249 & 12.59 & 0.17 \\
\hline & & & & & 2888 & 5.09 & 1.83 & 11.45 & 451 & 225 & 13.28 & 0.16 \\
\hline & & & & & 2892 & 3.42 & 1.36 & 8.52 & 454 & 249 & 9.88 & 0.16 \\
\hline & & & & & 2900 & 2.40 & 0.64 & 6.36 & 447 & 265 & 7.00 & 0.10 \\
\hline & & & & & 2908 & 2.98 & 1.20 & 6.68 & 450 & 224 & 7.88 & 0.18 \\
\hline & & & & & 2912 & 3.36 & 1.61 & 8.06 & 450 & 240 & 9.67 & 0.20 \\
\hline & & & & & 2916 & 3.44 & 1.33 & 7.40 & 448 & 215 & 8.73 & 0.18 \\
\hline & & & & & 2938 & 2.04 & 0.83 & 5.20 & 438 & 255 & 6.03 & 0.16 \\
\hline & & & & & c0849: & sdr:ifftc & trall.êm & 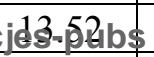 & 449 & 284 & 14.87 & 0.10 \\
\hline & & & & & 2984 & 6.70 & 1.26 & 25.19 & 432 & 376 & 26.45 & 0.05 \\
\hline
\end{tabular}




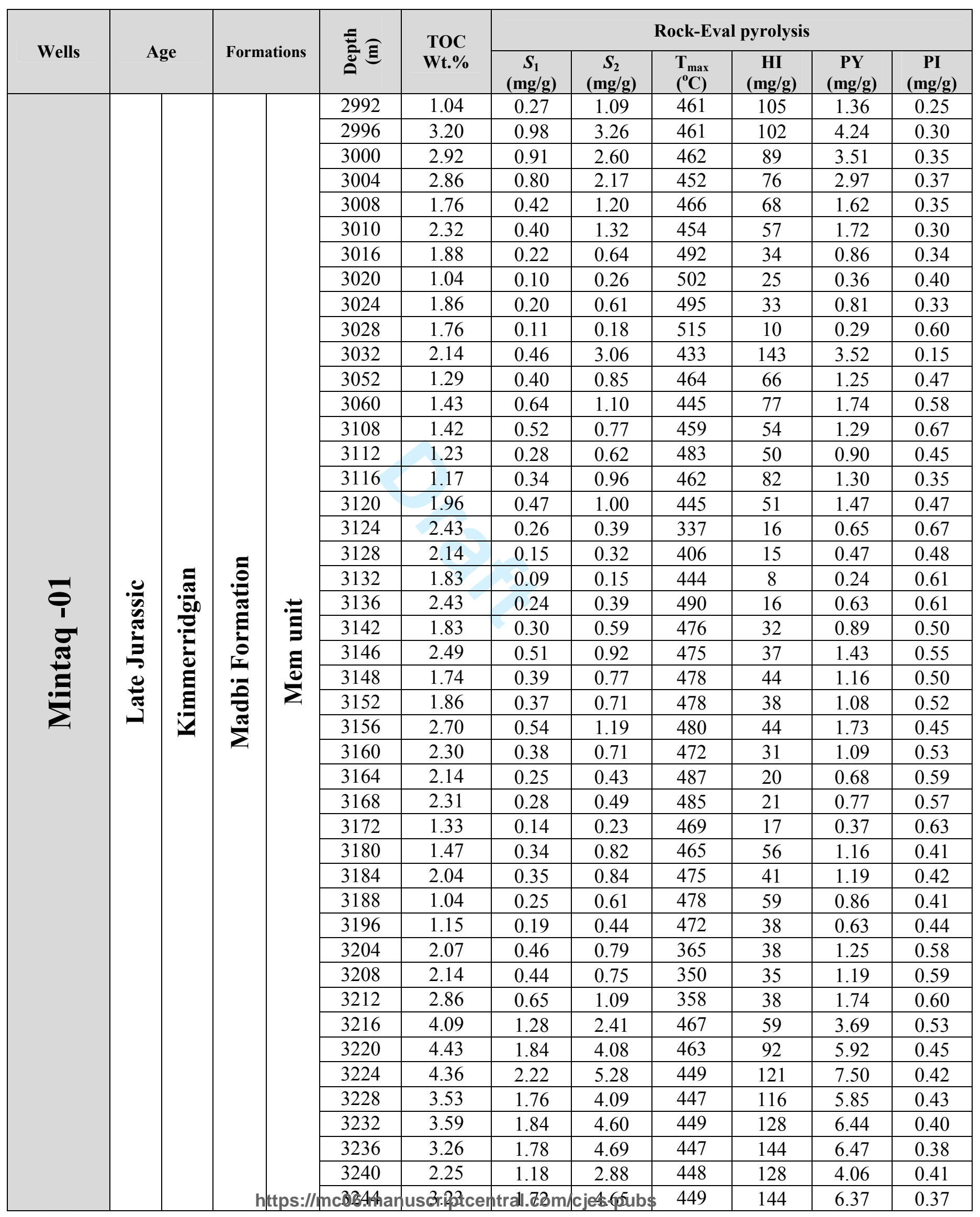




\begin{tabular}{|c|c|c|c|c|c|c|c|c|c|c|c|c|}
\hline \multirow{2}{*}{ Wells } & \multirow{2}{*}{\multicolumn{2}{|c|}{ Age }} & \multirow{2}{*}{\multicolumn{2}{|c|}{ Formations }} & \multirow{2}{*}{ 䓂卤 } & \multirow{2}{*}{$\begin{array}{c}\text { TOC } \\
\text { Wt. } \%\end{array}$} & \multicolumn{6}{|c|}{ Rock-Eval pyrolysis } \\
\hline & & & & & & & $\begin{array}{c}S_{1} \\
(\mathrm{mg} / \mathrm{g})\end{array}$ & $\begin{array}{c}S_{2} \\
(\mathrm{mg} / \mathrm{g})\end{array}$ & $\begin{array}{l}T_{\max } \\
\left({ }^{\circ} \mathrm{C}\right)\end{array}$ & $\begin{array}{c}\mathrm{HI} \\
(\mathrm{mg} / \mathrm{g})\end{array}$ & $\begin{array}{c}P Y \\
(\mathrm{mg} / \mathrm{g})\end{array}$ & $\begin{array}{c}\mathbf{P I} \\
(\mathrm{mg} / \mathrm{g})\end{array}$ \\
\hline \multirow{43}{*}{ 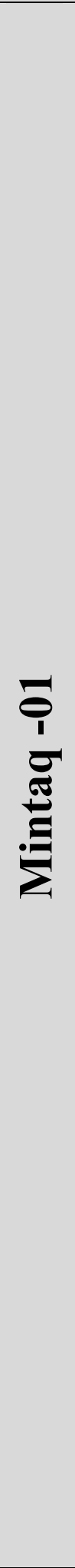 } & \multirow{43}{*}{ 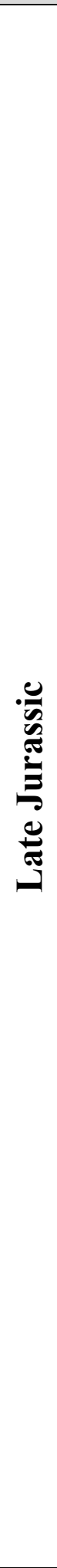 } & \multirow{43}{*}{ 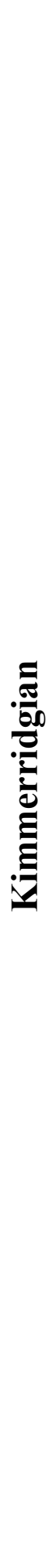 } & \multirow{43}{*}{ 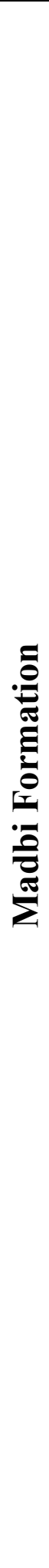 } & \multirow{43}{*}{ 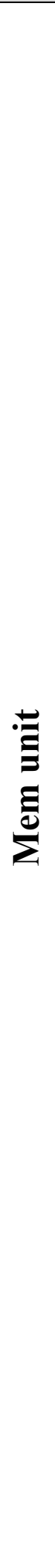 } & 3248 & 2.97 & 1.75 & 4.99 & 448 & 168 & 6.74 & 0.35 \\
\hline & & & & & 3252 & 3.01 & 1.58 & 4.79 & 450 & 159 & 6.37 & 0.33 \\
\hline & & & & & 3256 & 2.67 & 1.44 & 4.01 & 451 & 150 & 5.45 & 0.36 \\
\hline & & & & & 3260 & 2.40 & 1.36 & 4.25 & 453 & 177 & 5.61 & 0.32 \\
\hline & & & & & 3260 & 2.02 & 1.12 & 2.87 & 450 & 142 & 3.99 & 0.39 \\
\hline & & & & & 3270 & 1.79 & 0.97 & 2.86 & 451 & 160 & 3.83 & 0.34 \\
\hline & & & & & 3274 & 1.92 & 0.91 & 2.59 & 450 & 135 & 3.50 & 0.35 \\
\hline & & & & & 3276 & 2.36 & 0.99 & 3.66 & 455 & 155 & 4.65 & 0.27 \\
\hline & & & & & 3282 & 1.98 & 0.79 & 2.81 & 451 & 142 & 3.60 & 0.28 \\
\hline & & & & & 3286 & 2.85 & 1.06 & 4.08 & 454 & 143 & 5.14 & 0.26 \\
\hline & & & & & 3290 & 2.69 & 0.95 & 3.66 & 453 & 136 & 4.61 & 0.26 \\
\hline & & & & & 3454 & 1.10 & 0.34 & 1.16 & 459 & 105 & 1.50 & 0.29 \\
\hline & & & & & 3462 & 1.12 & 0.44 & 1.20 & 456 & 107 & 1.64 & 0.37 \\
\hline & & & & & 3466 & 1.47 & 0.50 & 1.68 & 459 & 114 & 2.18 & 0.30 \\
\hline & & & & & 3472 & 1.49 & 0.50 & 1.56 & 460 & 105 & 2.06 & 0.32 \\
\hline & & & & & 3474 & 1.66 & 0.60 & 2.01 & 459 & 121 & 2.61 & 0.30 \\
\hline & & & & & 3480 & 1.36 & 0.46 & 1.48 & 457 & 109 & 1.94 & 0.31 \\
\hline & & & & & 3484 & 2.04 & 0.79 & 2.73 & 461 & 134 & 3.52 & 0.29 \\
\hline & & & & & 3488 & 2.17 & 0.85 & 2.73 & 459 & 126 & 3.58 & 0.31 \\
\hline & & & & & 3492 & 2.06 & 0.81 & 2.37 & 459 & 115 & 3.18 & 0.34 \\
\hline & & & & & 3496 & 2.18 & 0.81 & 2.79 & 455 & 128 & 3.18 & 0.35 \\
\hline & & & & & 3500 & 2.37 & 0.98 & 3.03 & 455 & 128 & 3.77 & 0.33 \\
\hline & & & & & 3504 & 2.30 & 1.00 & 2.81 & 456 & 122 & 4.03 & 0.34 \\
\hline & & & & & 3508 & 2.34 & 0.96 & 2.48 & 459 & 106 & 3.77 & 0.36 \\
\hline & & & & & 3512 & 2.53 & 0.89 & 2.68 & 454 & 106 & 3.37 & 0.35 \\
\hline & & & & & 3516 & 2.50 & 0.94 & 2.83 & 456 & 113 & 3.62 & 0.36 \\
\hline & & & & & 3520 & 2.59 & 1.02 & 2.90 & 455 & 112 & 3.85 & 0.36 \\
\hline & & & & & 3524 & 2.64 & 1.04 & 2.82 & 449 & 107 & 3.94 & 0.21 \\
\hline & & & & & 3528 & 3.16 & 0.59 & 3.60 & 456 & 114 & 3.41 & 0.35 \\
\hline & & & & & 3532 & 2.81 & 1.26 & 2.84 & 456 & 101 & 4.86 & 0.34 \\
\hline & & & & & 3540 & 2.44 & 0.97 & 2.39 & 457 & 98 & 3.81 & 0.31 \\
\hline & & & & & 3544 & 1.60 & 0.74 & 1.62 & 454 & 101 & 3.13 & 0.34 \\
\hline & & & & & 3548 & 1.73 & 0.55 & 1.78 & 456 & 103 & 2.17 & 0.32 \\
\hline & & & & & 3552 & 1.56 & 0.57 & 1.15 & 460 & 74 & 2.35 & 0.38 \\
\hline & & & & & 3556 & 1.52 & 0.44 & 1.28 & 459 & 84 & 1.59 & 0.37 \\
\hline & & & & & 3562 & 1.76 & 0.47 & 1.55 & 410 & 88 & 1.75 & 0.34 \\
\hline & & & & & 3566 & 1.20 & 0.53 & 1.24 & 443 & 103 & 2.08 & 0.34 \\
\hline & & & & & 3570 & 1.10 & 0.42 & 1.02 & 445 & 93 & 1.66 & 0.34 \\
\hline & & & & & 3574 & 1.49 & 0.35 & 1.27 & 441 & 85 & 1.37 & 0.37 \\
\hline & & & & & 3576 & 2.40 & 0.47 & 1.75 & 444 & 73 & 1.74 & 0.49 \\
\hline & & & & & 3578 & 1.67 & 0.86 & 1.74 & 461 & 104 & 2.61 & 0.37 \\
\hline & & & & & 3586 & 1.29 & 0.64 & 1.23 & 456 & 95 & 2.38 & 0.35 \\
\hline & & & & & 3590 & 1.03 & 0.43 & 0.56 & 460 & 54 & 1.66 & 0.46 \\
\hline
\end{tabular}

TOC: Total organic Carbon, wt\%

$\mathrm{S}_{2}$ : Remaining $\mathrm{HC}$ generative potential, $\mathrm{mg} \mathrm{HC} / \mathrm{g}$ rock HI: Hydrogen Index $=S_{2} \mathrm{x} 100 / \mathrm{TOC}, \mathrm{mg} \mathrm{HC} / \mathrm{g}$ TOC PY: Potential Yield $=S_{1}+S_{2}(\mathrm{mg} / \mathrm{g})$
$S_{1}$ : Volatile hydrocarbon (HC) content, $\mathrm{mg} \mathrm{HC} / \mathrm{g}$ rock

$T_{\text {max }}$ : Temperature at maximum of $S_{2}$ peak

PI: Production Index $=S_{1} /\left(S_{1}+S_{2}\right)$ 
Table 2

Basin model input data used to reconstruct the burial history for studied well (Mintaq-01), Wadi Hajar sub-basin, Yemen.

\begin{tabular}{|c|c|c|c|c|c|c|c|c|c|c|c|c|}
\hline \multirow{2}{*}{ 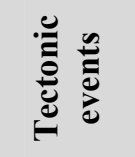 } & \multirow{2}{*}{ Formations } & \multicolumn{2}{|c|}{ Deposition age } & \multicolumn{2}{|c|}{ Erosion age } & \multirow{2}{*}{ 氞 } & \multicolumn{2}{|c|}{ Calibration data } & \multirow{2}{*}{ Lithology } & \multicolumn{3}{|c|}{ Mintaq-01 well } \\
\hline & & $\begin{array}{l}\text { From } \\
\text { (Ma) }\end{array}$ & $\begin{array}{l}\text { To } \\
(\mathbf{M a})\end{array}$ & $\begin{array}{l}\text { From } \\
\text { (Ma) }\end{array}$ & $\begin{array}{c}\text { To } \\
\text { (Ma) }\end{array}$ & & VRo (\%) & $\begin{array}{c}\text { Temperature } \\
\left({ }^{\circ} \mathrm{C}\right)\end{array}$ & & $\begin{array}{l}\text { Top } \\
\text { (m) }\end{array}$ & $\begin{array}{c}\text { Bottom } \\
\text { (m) }\end{array}$ & $\begin{array}{c}\text { Thickness } \\
\text { (m) }\end{array}$ \\
\hline Sedimen & surface & 24.9 & 0 & & & & & & Recent sediments & 0.0 & 10 & 10 \\
\hline \multirow{9}{*}{ 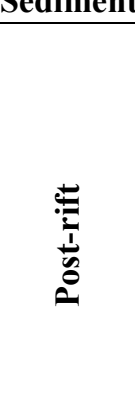 } & Habshiyah & 40.6 & 24.9 & & & & & & Limestone \& Shale \& Dolomite & 10 & 43 & 33 \\
\hline & Rus & 43.2 & 40.6 & & & 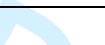 & & & Evaporite \& Dolomite & 43 & 217 & 174 \\
\hline & Jiza & & & 58.7 & 43.2 & 100 & & & Evaporite \& Shale & ------ & ------- & --------- \\
\hline & Umm Er Radhuma & 65.5 & 58.7 & & & & & & Limestone and interbedded shale & 217 & 453 & 236 \\
\hline & Sharwayn & & & 71.0 & 65.5 & 150 & 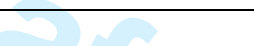 & & Sandstones \& Shale and carbonates & ------ & ב------- & -------- \\
\hline & Mukalla & 93.5 & 71.0 & & & & $0.38-0.40\left(\mathrm{R}_{\mathrm{o}} \%\right)$ & & Sandstone \& Shale \& Coal & 453 & 1050 & 597 \\
\hline & Harshiyat/ Fartaq & 112 & 93.5 & & & & $0.48-0.53\left(\mathrm{R}_{0} \%\right)$ & $1190 \mathrm{~m}-55^{\circ} \mathrm{C}$ & Sandstones and shale interbedded & 1050 & 1259 & 209 \\
\hline & Qishn & 136.4 & 112 & & & & $0.55-0.56\left(\mathrm{R}_{0} \%\right)$ & & Sandstones and carbonates & 1259 & 1337 & 78 \\
\hline & Saar & & & 140.2 & 136.4 & 250 & & & Limestone \& Shale \& Dolomite \& Sandstone & ------ & ------- & -------- \\
\hline & Naifa & 146.3 & 140.2 & & & & ------------- & & Limestone and shales & 1337 & 1549 & 212 \\
\hline \multirow{3}{*}{ 离 } & Safer & 148.0 & 146.3 & & & & 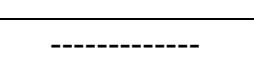 & & Sandstones, shales and evaporites & 1549 & 2329 & 780 \\
\hline & Upper Madbi (Lam) & 150.8 & 148.0 & & & & $0.55-0.79\left(\mathrm{R}_{\mathrm{o}} \%\right)$ & $2450 \mathrm{~m}-95^{\circ} \mathrm{C}$ & Organic-rich shales and sandstones & 2329 & 2989 & 660 \\
\hline & $\begin{array}{l}\text { Lower Madbi } \\
\text { (Meem) }\end{array}$ & 155.7 & 150.8 & & & & $1.12\left(\mathrm{R}_{\mathrm{o}} \%\right)$ & & Organic-rich shales and sandstones & 2989 & 3647 & 658 \\
\hline \multirow{3}{*}{ Pre-rift } & Shuqra & 161.2 & 155.7 & & & & ------------- & $3650 \mathrm{~m}-125^{\circ} \mathrm{C}$ & Massive Limestone and interbedded shale & 3647 & 3682 & 35 \\
\hline & Kuhlan & 163.0 & 161.2 & & & & ------------- & & Sandstones & 3682 & 3711 & 29 \\
\hline & Basement & $<170.0$ & 163.0 & & & & & & Granite and metamorphic rocks & 3711 & 3759 & 48 \\
\hline
\end{tabular}

